
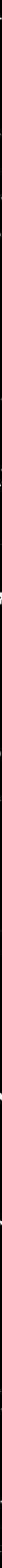

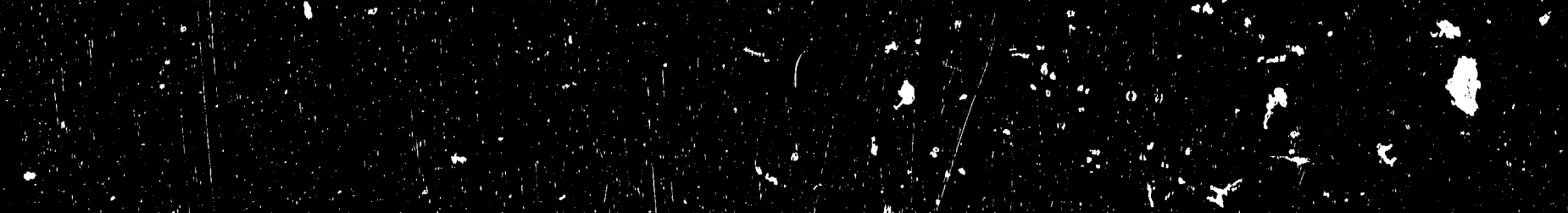

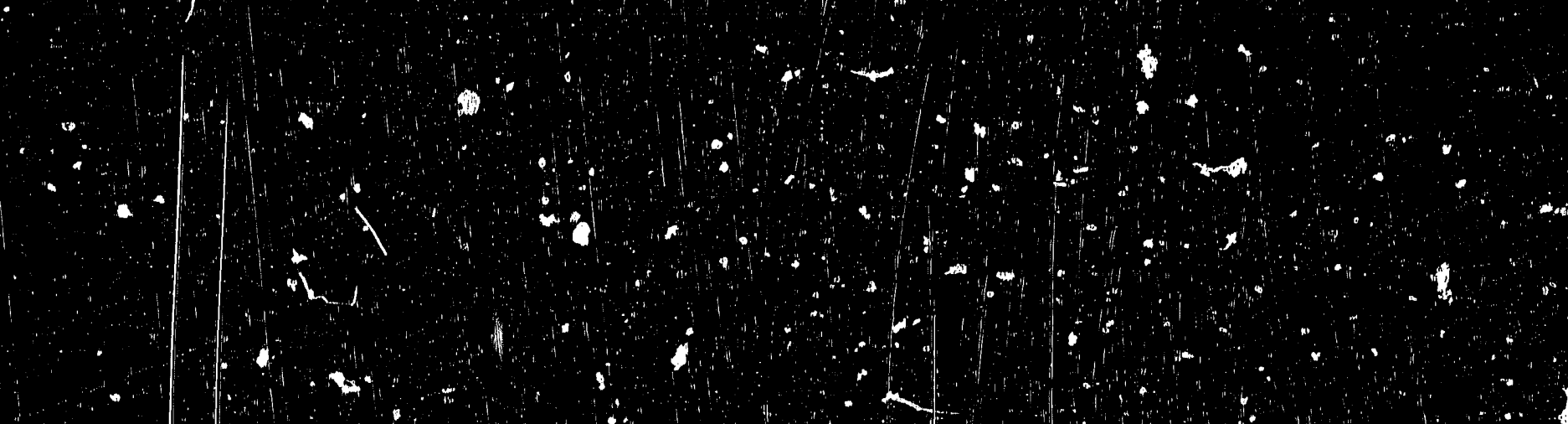


Metals and Ceramics Division

\title{
METALLIC PHASE-CHANGE MATERIALS FOR SOLAR DYNAMIC ENERGY STORAGE SYSTEMS
}

\author{
R. J. Lauf and C. Hamby, Jr.
}

Date Published: December 1990

NOTICE: This document contains information of a preliminary nature. It is subject to revision or correction and therefore does not represent a final report.

Work supported by

NASA Lewis Research Center (NASA Order No. C-30003-J)

Advanced Solar Dynamic Program

\author{
Prepared by the \\ OAK RIDGE NATIONAL LABORATORY \\ Oak Ridge, Tennessee 37831-6285 \\ managed by \\ MARTIN MARIETTA ENERGY SYSTEMS, INC. \\ for the \\ U.S. DEPARTMENT OF ENERGY \\ under contract DE-AC05-84OR21400
}




\section{CONTENTS}

LIST OF TABLES $\ldots \ldots \ldots \ldots \ldots \ldots \ldots \ldots \ldots \ldots \ldots \ldots \ldots$

LIST OF FIGURES $\ldots \ldots \ldots \ldots \ldots \ldots \ldots \ldots \ldots \ldots \ldots \ldots \ldots \ldots$

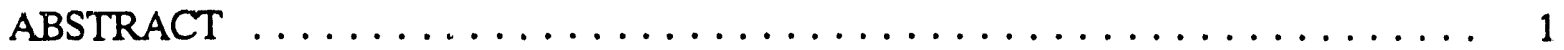

1. INTRODUCTION $\ldots \ldots \ldots \ldots \ldots \ldots \ldots \ldots \ldots \ldots \ldots \ldots \ldots$

2. FABRICATION AND TESTING OF THERMAI, STORAGE MODULES . . . . 5

2.1 GERMANIUM AND ITS ALLOYS ............... 9

2.1 .1 Sessile Drop . . . . . . . . . . . . . . . . . 9

2.1.2 Test Capsule ............................ 9

2.1 .3 Prototype Capsules $\ldots \ldots \ldots \ldots \ldots \ldots \ldots \ldots \ldots \ldots$

$2.2 \mathrm{Mg}_{2} \mathrm{Si}-\mathrm{Si}$ EUTECTIC $\ldots \ldots \ldots \ldots \ldots \ldots \ldots \ldots \ldots \ldots \ldots \ldots$

2.2 .1 Test Capsules $\ldots \ldots \ldots \ldots \ldots \ldots \ldots \ldots \ldots \ldots \ldots \ldots \ldots$

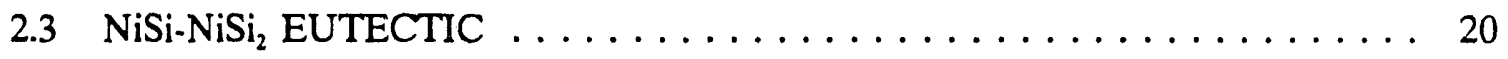

2.3 .1 Sessile Drop . . . . . . . . . . . . . . . . 20

2.3.2 Test Capsules . . . . . . . . . . . . . . . . . . 20

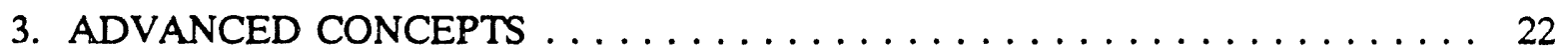

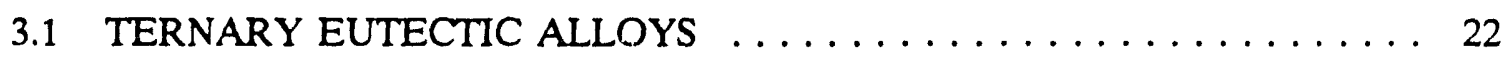

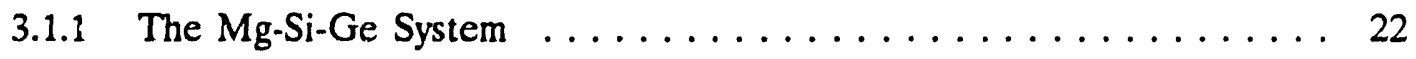

3.1 .2 The Ni-Si-Ge System . . . . . . . . . . . . . . . . 24

3.2 INFILTRATION TO CONTROL MELT GEOMETRY . . . . . . . . . . 25

4. CONCLUSIONS ......................... 31

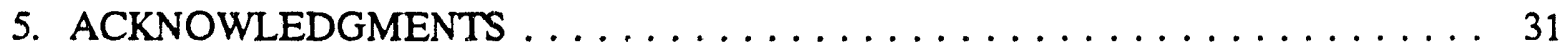

6. REFERENCES ............................ 32

Appendix: SUMMARY OF MELTING TESTS $\ldots \ldots \ldots \ldots \ldots \ldots \ldots$ 


\section{LIST OF TABLES}

Table 1. State-of-the-art heat storage system for Brayton

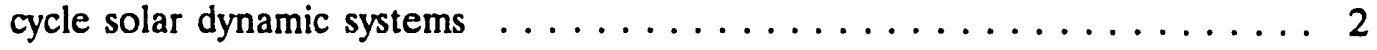

Table 2. Four groups of Si alloy phase-change materials $\ldots \ldots \ldots \ldots \ldots \ldots$

Table 3. Properties of candidate phase-change materials $\ldots \ldots \ldots \ldots \ldots \ldots$

Table 4. Graphite properties and chemistry $\ldots \ldots \ldots \ldots \ldots$

Table 5. Comparison of heat storage systems $\ldots \ldots \ldots \ldots$ 


\section{LIST OF FIGURES}

Fig. 1. Graphite test capsule with threaded closure, designed

to hold $85 \mathrm{~g} \mathrm{Ge}$ and store $38 \mathrm{~kJ}$ of latent heat at $1210 \mathrm{~K} \ldots \ldots \ldots \ldots$

Fig. 2. Graphite prototype capsules of two designs: left, hollow annulus; right, drilled cavities $\ldots \ldots \ldots \ldots \ldots \ldots \ldots \ldots$

Fig. 3. Interior of vacuum furnace, showing cold finger used to cool the inside diameter of the prototype capsule during thermal cycling. Top: cold finger (note test capsule behind it on the right). Bottom: prototype capsule in place, with $\mathrm{CBCF}$

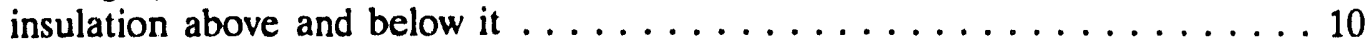

Fig. 4. Sessile drop of Ge-0.5\% Ti alloy on a spectoscopic carbon planchette. Wetting angle $\theta \approx 150^{\circ} \ldots \ldots \ldots \ldots \ldots \ldots \ldots$

Fig. 5. Sessile drop of Ge-0.5\% Si alloy on a spectoscopic carbon

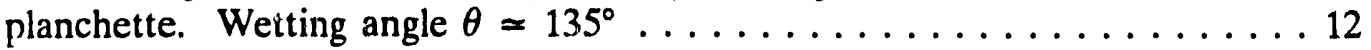

Fig. 6. Test capsule containing pure Ge, showing structure that forms by expansion of the Ge upon solidification $\ldots \ldots \ldots \ldots \ldots$

Fig. 7. Weight loss data for several test capsules. Each cycle consists of $1 \mathrm{~h}$ at $773 \mathrm{~K}$ and $2 \mathrm{~h}$ at $1273 \mathrm{~K}$. The weight loss from an empty graphite capsule (curve with open triangles) represents the weight loss caused by graphite oxidation. Anomalous losses from one Ge sample were the result of metal adhesion to the threaded closure . . . . . . . . . . . 15

Fig. 8. Weight loss data for two prototype capsules containing Ge and for one empty test capsule. The weight loss from the 2020 prototype capsule was mainly the result of Ge loss by seepage. The loss from the test capsule represents graphite oxidation. Weight losses from the POCO AXF-5Q prototype capsule were extremely low . . . . . . . . . . . . . 15

Fig. 9. $\mathrm{Mg}_{2} \mathrm{Si}$-Si eutectic alloy forming a thin meniscus on the inner surface of a Stackpole 2020 test capsule. Note restructured layer in the graphite (arrows) $\ldots \ldots \ldots \ldots \ldots \ldots$

Fig. 10. Detail of $\mathrm{Mg}_{2} \mathrm{Si}-\mathrm{Si}$ on graphite surface. Tote metal nodules about $100 \mu \mathrm{m}$ into the graphite (arrows) . . . . . . . . . . . . 19

Fig. 11. Sessile drop of $\mathrm{NiSi}-\mathrm{NiSi}_{2}$ eutectic on spectroscopic carbon planchette. Note penetration of the metal into the graphite substrate (arrow). Wetting angle $\theta \approx 110^{\circ} \ldots \ldots \ldots \ldots \ldots \ldots$ 
Fig. 12. Postulated Mg-Si-Ge ternary phase diagram, constructed from

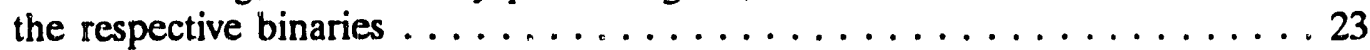

Fig. 13. Mg-Si-Ge alloy melted at $1373 \mathrm{~K}$ and furnace cooled. Microstructure consists of cored dendrites of Ge-Sii solid solution surrounded by a Si-poor eutectic approxi-

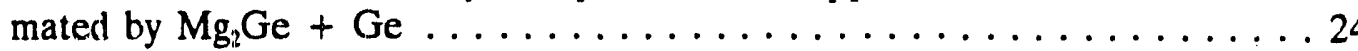

Fig. 14. Scanning electron micrographs of low-density CBCF composite. Top: general structure at $20 \times(\mathrm{bar}=1 \mathrm{~mm})$. Bottom: detail showing fiber arrangement at $100 \times($ bar $=100 \mu \mathrm{m}) \ldots \ldots 26$

Fig. 15. Test capsule containing $\mathrm{Mg}_{2} \mathrm{Si}-\mathrm{Si}$ eutectic composition and a thin CBCF wick. Note how surface tension has drawn the molten alloy up into the wick (arrow) $\ldots \ldots \ldots \ldots \ldots \ldots \ldots \ldots \ldots \ldots \ldots$

Fig. 16. Test capsule containing a rectangular CBCF preform infiltrated with $\mathrm{NiSi}-\mathrm{NiSi}_{2}$ eutectic formed by melting the

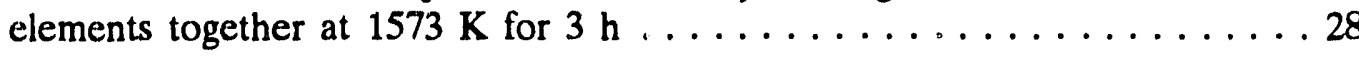

Fig. 17. Scanning electron micrographs of carbon foam.

Top: overview of structure at $19 \times$ showing distribution of void diameters (bar $=1 \mathrm{~mm}$ ). Bottom: detail showing open passages $(-50 \mu \mathrm{m})$ between voids at

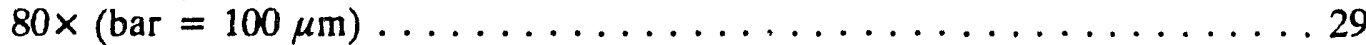

Fig. 18. Scanning electron micrographs of carbon foam exposed to $\mathrm{NiSi}-\mathrm{NiSi}_{2}$. One can see that the alloy has penetrated into the porous matrix by wetting the surface.

Top: overview showing uniformity of the coating at $80 \times($ bar $=100 \mu \mathrm{m})$. Bottom: detail at $500 \times$ showing that the alloy forms a nearly continuous film $($ bar $=10 \mu \mathrm{m}) \ldots \ldots . \ldots 30$ 


\title{
METALLIC PHASE-CHANGE MATERIALS FOR SOLAR DYNAMIC ENERGY STORAGE SYSTEMS*
}

\author{
R. J. Lauf and C. Hamby, Jr.
}

\begin{abstract}
Solar (thermal) dynamic power systems for satellites require a heat storage system that is capable of operating the engine during eclipse. The conventional approach to this thermal storage problem is to use the latent heat of fluoride salts, which would melt during insolation and freeze during eclipse. Although candidate fluorides have large heats of fusion per unit mass, their poor thermal conductivity limits the rate at which energy can be transferred to and from the storage device. System performance is further limited by the high parasitic mass of the superalloy canisters needed to contain the salt.

This report describes a new thermal storage system in which the phase-change material (PCM) is a metal (typically germanium) contained in modular graphite canisters. These modules exhibit good thermal conductivity and low parasitic mass, and they are physically and chemically stable. Prototype modules have survived over 600 melt/freeze cycles without degradation.

Advanced concepts to further improve performance are described. These concepts include the selection of ternary eutectic alloys to provide a wider range of useful melting temperatures and the use of infiltration to control the location of liquid alloy and to compensate for differences in thermal expansion.
\end{abstract}

\section{INTRODUCTION}

Solar dynamic power systems ${ }^{1-3}$ using either Brayton or Stirling engine cycles require a heat storage system capable of powering the engine at optimal efficiency during eclipse. Current baseline systems using the latent heat of melting of fluoride salts are

\footnotetext{
*Work supported by NASA Lewis Research Center under interagency agreement no. 1819-1819-Al under Martin Marietta Energy Systems, Inc., contract DE-AC05-84OR21400 with the U.S. Departmeat of Energy.
} 
limited by, among other things, the poor thermal conductivity of the salt and the large parasitic mass of the metal containers. For example, the heat of fusion of $\mathrm{LiF}-20 \% \mathrm{CaF}_{2}$ is $815 \mathrm{~kJ} / \mathrm{kg}$, but when the mass of the Haynes 188 canister is included, the system storage capacity becomes only $300 \mathrm{~kJ} / \mathrm{kg}$ (Table 1 ).

Table 1. State-of-the-art heat storage system for Brayton cycle solar dynamic systems

\begin{tabular}{ll}
\hline & $P C M$ \\
Miaterial & \\
Melt temperature & $\mathrm{LiF}-20 \% \mathrm{CaF}_{2}$ \\
Heat of fusion & $1040 \mathrm{~K}$ \\
$\quad$ Specific & $815 \mathrm{~kJ} / \mathrm{kg}$ \\
$\quad$ Volumetric & $1.71 \mathrm{~kJ} / \mathrm{cm}^{3}$ \\
Thermal conductivity & \\
$\quad$ Solid & $4.0 \mathrm{~W} / \mathrm{m} \cdot \mathrm{K}$ \\
Liquid & $1.6 \mathrm{~W} / \mathrm{m} \cdot \mathrm{K}$ \\
Density, liquid & $2.1 \mathrm{~g} / \mathrm{cm}^{3}$ \\
Void formation & $22 \% \Delta \mathrm{V} / \mathrm{V}_{1}$
\end{tabular}

\section{Container}

\section{Material}

Maximum temperature

Haynes 188

$\sim 1100 \mathrm{~K}$

System

Specific heat storage ${ }^{a}$ (maximum) $\quad 300 \mathrm{~kJ} / \mathrm{kg}$ Volumetric heat storage ${ }^{a}$ (maximum) $1.3 \mathrm{~kJ} / \mathrm{cm}^{3}$

\footnotetext{
${ }^{a}$ Estimated using the dimensions of a heat storage canister proposed for a space station system, assuming complete melting and freezing of the PCM in each cycle.
}

Higher thermal conductivity $\left(\mathrm{k}_{\mathrm{th}}\right)$ would improve performance by allowing more of the PCM to melt in a given time with a given $\Delta T$. One obvious way to increase $k_{\text {th }}$ is to use a metal as the PCM. Most liquid metals with melting temperatures in the range of interest $(1100-1200 \mathrm{~K})$ are extremely corrosive to other metals, suggesting the need for a ceramic container. Because ceramics are inherently brittle, the design must accommodate differential thermal expansion as well as any volume change on melting. The system must survive melting and freezing every $1.5 \mathrm{~h}$ for 10 years (about $58,000 \mathrm{melt} / \mathrm{freeze}$ cycles) and tolerate an occasional cooldown to ambient. 
Previously, Wichner, Schmidt, and DeVan at Oak Ridge National Laboratory examined many alloy systems for possible candidate PCMs. Three types of alloys were considered:

1. congruently melting line compounds or elements, in which a single solid phase of fixed composition is in equilibrium with a single liquid $p^{2}$ ase at its melting point;

2. eutectics, in which two solid phases are in equilibrium with a single liquid phase at the eutectic temperature; and

3. solid solutions, in which a single solid phase melts incongruently between the solidus and liquidus temperatures.

Congruently melting line compounds, elements, and eutectics are particularly appropriate as PCMs, because they theoretically release energy isothermally on solidification. Solid solutions are less appropriate as PCMs because of macrosegregation, which is likely to occur from multiple freeze/melt cycles. This segregation might shift the melting range of the PCM.

Wichner et al. organized the candidate PCMs into four groups based on their likely chemical properties (Table 2). Of these, we selected three materials for near-term development: $\mathrm{Ge}$ (element), $\mathrm{Mg}_{2} \mathrm{Si}-\mathrm{Si}$ (eutectic), and $\mathrm{NiSi}-\mathrm{NiSi}_{2}$ (eutectic). The properties of these three PCMs, and those of $\mathrm{LiF}-\mathrm{CaF}_{2}$ for comparison, are listed in Table 3. Pure Ge melts at $1210 \mathrm{~K}$, and on melting there is a volume decrease of nearly $5 \%$. Any capsule design must therefore take into account the corresponding expansion on freezing. The $\mathrm{Mg}_{2} \mathrm{Si}$-Si eutectic melts at $1219 \mathrm{~K}$ and also appears to expand somewhat on freezing. The NiSi-NiSi ${ }_{2}$ eutectic melts at $1239 \mathrm{~K}$ with little (if any) volume change.

As originally conceived these alloys were to be formed into small beads and coated with thin layers of SiC by chemical vapor deposition. The coated PCM particles would then be dispersed in a graphitic matrix tha could be extruded into convenient shapes (e.g., cylinders). This technology is well known, having been developed originally for the High-Temperature Gas-Cooled Reactor ${ }^{4}$ (HTGR).

Although the microsphere concept could, in principle, contain the PCM reliably, its major drawback is the large parasitic mass (and volume) of coating and matrix. Therefore, we adopted a simpler design in which a large mass of PCM was contained directly in a ceramic canister. Graphite was chosen as the container material because of its excellent 
Table 2. Four groups of Si alloy phase-change materials

\begin{tabular}{|c|c|c|c|}
\hline & & $\begin{array}{l}\mathrm{T}_{\mathrm{m}} \\
(\mathrm{K})\end{array}$ & $\begin{array}{c}\Delta H_{\mathrm{m}} \\
(\mathrm{kJ} / \mathrm{kg})\end{array}$ \\
\hline & \multicolumn{3}{|c|}{ Group VIILA - Si Systems } \\
\hline PdSi-Si & Eutectic & 1143 & 480 \\
\hline PdSi & Compound & 1363 & 520 \\
\hline $\mathrm{NiSi}-\mathrm{NiSi}_{2}$ & Eutectic & 1239 & 640 \\
\hline $\mathrm{NiSi}$ & Compound & 1265 & 750 \\
\hline $\mathrm{Fe}_{2} \mathrm{Si}_{5}-\mathrm{Si}$ & Eutectic & 1480 & 1000 \\
\hline $\mathrm{FeSi}-\mathrm{Fe}_{2} \mathrm{Si}_{5}$ & Eutectic & 1485 & 900 \\
\hline \multirow[t]{2}{*}{$\mathrm{Fe}_{2} \mathrm{Si}_{5}$} & Compound & 1493 & 1180 \\
\hline & \multicolumn{3}{|c|}{ Group VILA - Si Systems } \\
\hline \multirow{3}{*}{$\begin{array}{l}\mathrm{Mn}_{11} \mathrm{Si}_{19} \\
\mathrm{ReSi}_{2}-\mathrm{Si}\end{array}$} & Compound & 1418 & 1130 \\
\hline & Eutectic & 1398 & 948 \\
\hline & \multicolumn{3}{|c|}{ Group IIA - Si Systems } \\
\hline $\mathrm{Be}-\mathrm{Si}$ & Eutectic & 1363 & 1350 \\
\hline $\mathrm{Mg}_{2} \mathrm{Si}-\mathrm{Si}$ & Eutectic & 1219 & $800-1000$ \\
\hline $\mathrm{Mg}_{2} \mathrm{Si}$ & Compound & 1358 & 1100 \\
\hline $\mathrm{CaSi}_{2}-\mathrm{Si}$ & Eutectic & 1253 & 1100 \\
\hline $\mathrm{SrSi}_{2}-\mathrm{Si}$ & Eutectic & 1273 & 870 \\
\hline $\mathrm{SrSi}-\mathrm{SrSi}_{2}$ & Eutectic & 1317 & 660 \\
\hline $\mathrm{SrSi}_{2}$ & Compound & 1423 & 850 \\
\hline \multirow[t]{2}{*}{$\mathrm{BaSi}_{2}$} & Compound & 1453 & 630 \\
\hline & \multicolumn{3}{|c|}{ Ge-Si Solution Systems } \\
\hline $\mathrm{Ge}$ & Element & 1211 & 510 \\
\hline Ge-0.2Si & Solution & $1270-1400$ & 650 \\
\hline $\mathrm{Ge}-0.4 \mathrm{Si}$ & Solution & $1340-1510$ & 830 \\
\hline Ge-0.6Si & Solution & $1430-1580$ & 1130 \\
\hline Ge-0.8Si & Solution & $1560-1640$ & 1330 \\
\hline $\mathrm{Si}$ & Element & 1687 & 1800 \\
\hline
\end{tabular}


Table 3. Properties of candidate phase-change materials

\begin{tabular}{|c|c|c|c|c|}
\hline Alloy & $\mathrm{T}_{\mathrm{m}}(\mathrm{K})$ & $\Delta H_{m}(k J / g)$ & $\Delta V_{m}(\%)$ & Comments \\
\hline $\mathrm{Ge}$ & 1210 & 481 & -4.75 & Pure element \\
\hline $\mathrm{Mg} \mathrm{Si}_{2} \mathrm{Si}$ & 1219 & $800-1000$ & & Eutectic \\
\hline $\mathrm{NiSi}-\mathrm{NiSi}_{2}$ & 1239 & 640 & & Eutectic \\
\hline $\mathrm{LiF}-20 \% \mathrm{CaF}_{2}$ & 1040 & 815 & +22 & $\begin{array}{l}\text { Salt system for } \\
\text { comparison }\end{array}$ \\
\hline
\end{tabular}

high-temperature properties, good thermal conductivity relative to other cerannics, and relatively low density. Graphite can be easily machined into large components that would be prohibitively difficult to make from structural ceramics such as silicon carbide or silicon nitride. The major shortcoming of graphite is helium permeability at high temperatures. Thus, containment of the woiking fluid (a mixture of $\mathrm{He}$ and $\mathrm{Xe}$ ) must be provided by refractory metai tubes thermally coupled to the graphite.

The various options for sealing the graphite modules, joining them together, and mating the assembly to the gas manifold are presently under consideration and will be reported elsewhere.

\section{FABRICATION AND TESTING OF THERMAL STORAGE MODULES}

The graphite capsules used in this study were machined frora two billets of Stackpole 2020 graphite $^{*}$ and one billet of POCO AXF-5Q. ${ }^{\dagger}$ The Stackpole 2020 was chosen because it represents a good grade of commercial graphite and had been well characterized in previous work. This graphite was available in two levels of purity, allowing us to test the effect oi metallic impurities on wetting or adhesion. The POCO AXF-5Q represenis a material with much finer porosity than the Stackpole 2020. This material was used after prototype capsules made from Stackpole 2020 began to lose some Ge, apparently by seepage through interconnected porosity. Properties of each type of graphite are summarized in Table 4.

\footnotetext{
*Stackpole Carbon $C_{\text {, }}$, St. Marys, Penn.

†POCO Graphite, Inc., Decatur, Tex.
} 
Table 4. Graphite properties and chemistry

\begin{tabular}{llll}
\hline Material $^{a}$ & $\begin{array}{c}\text { Stackpole 2020 } \\
\text { Grade 1 }\end{array}$ & $\begin{array}{c}\text { Stackpole 2020 } \\
\text { Grade 2 }\end{array}$ & POCO AXF-5Q \\
\hline Density, g/cm & & 1.78 & 1.79 \\
Flexure strength, MPa (psi) & $34.5(5000)$ & $34.5(5000)$ & $89.7(13,000)$ \\
Coefficient of thermal & & & \\
expansion, $10^{-6} / \mathrm{K}$ & 3.5 & 3.5 & 8.4 \\
Pore size, $\mu \mathrm{m}$ & 1.5 & 1.5 & 0.8 \\
Grain size $\mu \mathrm{m}$ & 40 & 40 & 4 \\
Impurities $b$ & & & \\
Ash, wt \% & 0.11 & 0.11 & 0.10 \\
$\mathrm{Fe}, \mathrm{ppm}$ & 11 & 110 & $5-30$ \\
$\mathrm{Si}, \mathrm{ppm}$ & 70 & 240 & $5-50$ \\
$\mathrm{Ca}, \mathrm{ppm}$ & 260 & 330 & $5-100$ \\
$\mathrm{Mg}, \mathrm{ppm}$ & 0.5 & 0.07 & $1-5$ \\
$\mathrm{Al}, \mathrm{ppm}$ & 16 & 115 & $10-50$ \\
$\mathrm{~V}, \mathrm{ppm}$ & 15 & $c$ & $100-500$ \\
\hline
\end{tabular}

$a_{\text {Grade } 1}$ and Grade 2 are internal sample numbers and are not the manufacturer's designation.

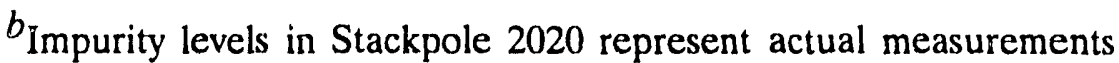
from nearby billet sections. Values for POCO AXF-5Q are maximum limits specified by manufacturer.

${ }^{c}$ Not determined.

Graphite capsules k'ere made in two sizes, which were designated "test" and "prototype" geometries. The test capsule was a cylindrical crucible with a threaded closure (Fig. 1). This capsule has a maximum capacity of $85 \mathrm{~g} \mathrm{Ge}$ for a theoretical storage capacity of $38 \mathrm{~kJ}$. Twelve capsules were machined from each grade of Stackpole 2020. They were used for initial screening studies to determine the most promising alloys for testing in the prototype geometry.

The prototype capsules were cylindrical $[7.6 \mathrm{~cm}(3$ in.) $\mathrm{OD} \times 2.5 \mathrm{~cm}(1$ in.) ID $\times$ $7.6 \mathrm{~cm}$ ( $3 \mathrm{in}$.) long], and designed to approximate heat storage modules that would slip over $\mathrm{Nb}-1 \mathrm{Zr}$ tubes carrying the working fluid in an actual solar dynamic power unit. These capsules are therefore directly analogous to the salt canisters of the baseline PCM system. Two prototype designs were tested. The first is a hollow annulus with a maximum capacity 


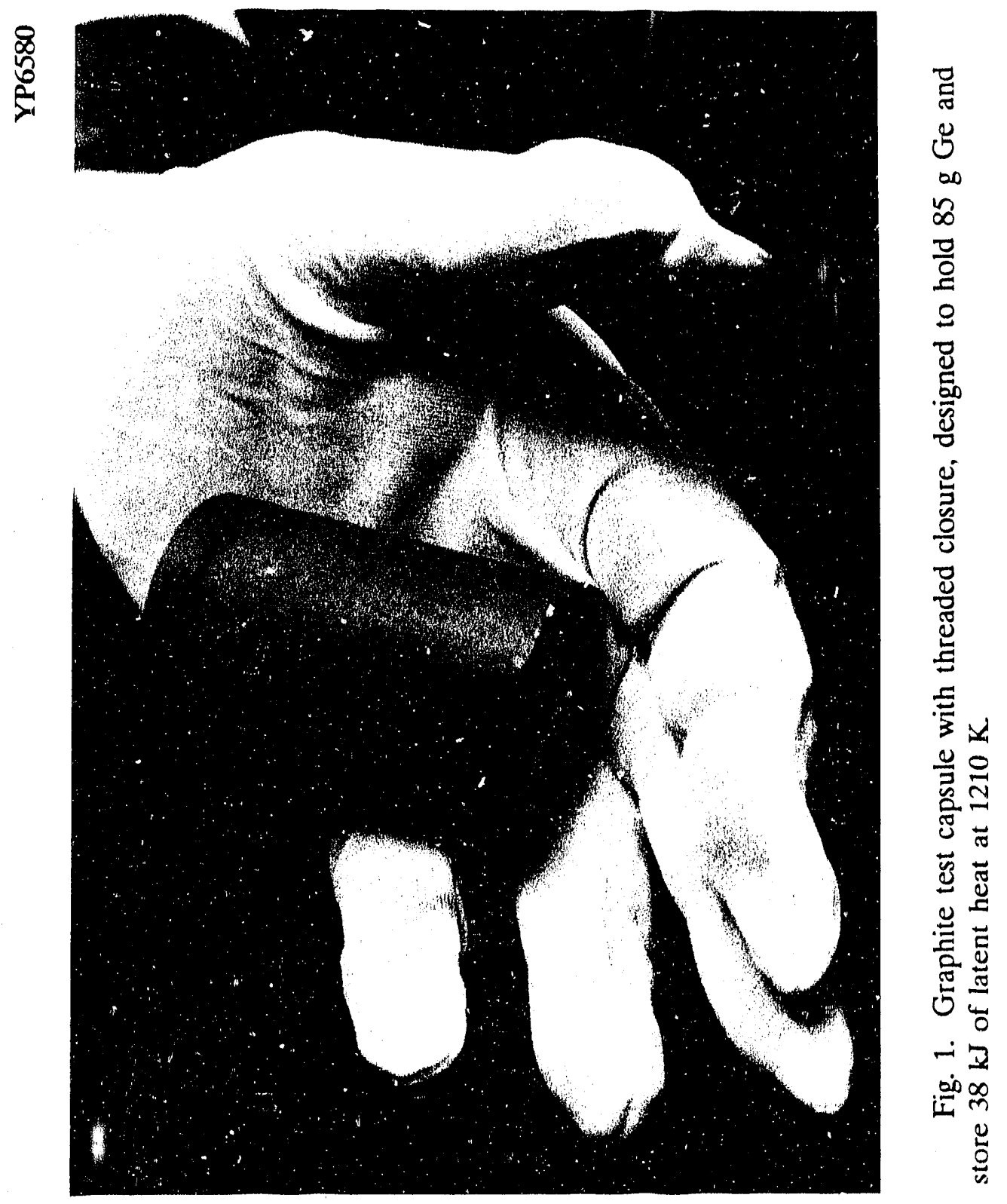


of $900 \mathrm{~g} \mathrm{Ge}$ and $440 \mathrm{~kJ}$ of latent heat. The second prototype design is a solid annulus with axially drilled cavities to contain the PCM. This module holds $750 \mathrm{~g}$ of Ge and stores $360 \mathrm{~kJ}$ of latent heat. Both capsules have threaded closures (Fig. 2).

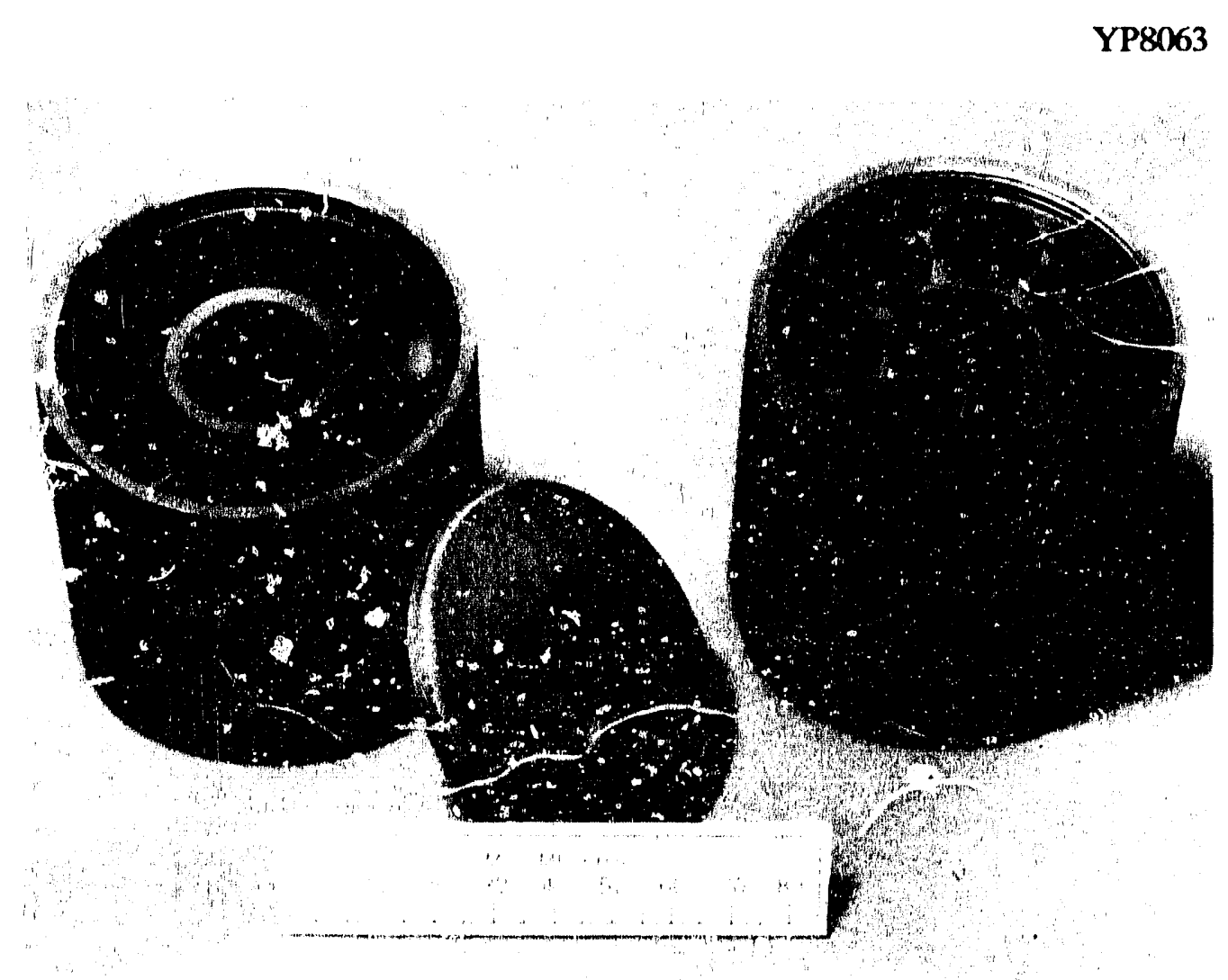

Fig. 2. Graphite prototype capsules of two designs: left, hollow annulus; right, drilled cavities.

Capsules of both test and prototype geometries were subjected to thermal cycling to test their ability not only to contain the molten PCM but also to accommodate volume changes on melting and differential thermal expansion between the PCM and the graphite capsu:e. Thermal cycle tests were done in a vacuum of about $10^{-6}$ torr. A typical cycle consisted of $1 \mathrm{~h}$ at $773 \mathrm{~K}$, heatup at $17 \mathrm{~K} / \mathrm{min}$ to $1273 \mathrm{~K}, 2 \mathrm{~h}$ at $127.3 \mathrm{~K}$, and cooldown at $11 \mathrm{~K} / \mathrm{min}$ to $773 \mathrm{~K}$. The furnace cr-ied auiomatically; periodically the samples were cooled to ambient, remover ior inspection and weighing, and returned for additional cycling. 
Initially, all specimens were arranged in the furnace cavity to melt and freeze isothermally (i.e., no forced cooling was provided, and heat transfer was predominantly radiative). Later, a stainless steel cold finger was designed to fit inside the bore of the prototype capsule and extract some of the heat with flowing nitrogen (Fig. 3). The purpose of forced cooling was to determine the influence of directional solidification on the movement of PCM within the capsule (recalling that Ge expands on freezing). In operation, layers of carbon-bonded carbon-fiber (CBCF) insulation were placed above and below the capsule in an effort to maintain a purely radial thermal gradient. Nitrogen was delivered to the cold finger through a solenoid activated by the furnace controller so that gas flowed only during the first $15 \mathrm{~min}$ of each cooldown cycle. This was more than adequate to extract the latent heat and completely solidify the PCM.

A complete summary of all tests (both thermal cycle and sessile drop) is given in the Appendix. In the discussion that follows, the test results are grouped according to the particular PCM to illustrate how each alloy system behaves during melting and freezing and how each interacts with its graphite container.

\subsection{GERMANIUM AND ITS ALLOYS}

\subsubsection{Sessile Drop}

The Ge-C system ${ }^{5}$ shows complete insolubility between the two elements. Sessile drop tests of pure Ge on porous $\mathrm{CBCF}$ and on a spectroscopic carbon planchette, both in vacuum at $1273 \mathrm{~K}$, confirmed that pure Ge does not wet graphite at all; the sessile drop was nearly spherical and did not adhere to the carbon on cooling. Using the standard notation, ${ }^{6}$ the contact angle $\theta=180^{\circ}$. To explore the possibility that some wetting might be desirable to improve heat transfer and to better control the location of the alloy within the container, two $\mathrm{Ge}$ alloys were made containing $0.5 \% \mathrm{Ti}$ and $0.5 \% \mathrm{Si}$, respectively. The contact angle of Ge-0.5\% $\mathrm{Ti}$ on a carbon planchette was $150^{\circ}$ and that of $\mathrm{Ge}-0.5 \% \mathrm{Si}$ was $135^{\circ}$, indicating that both additives increase wetting (Figs. 4 and 5).

\subsection{Test Capsules}

Pure Ge was melted in both Grade 1 and Grade 2 Stackpole graphite test capsules. The metal did not wet either grade of graphite; because of differential thermal expansion, 

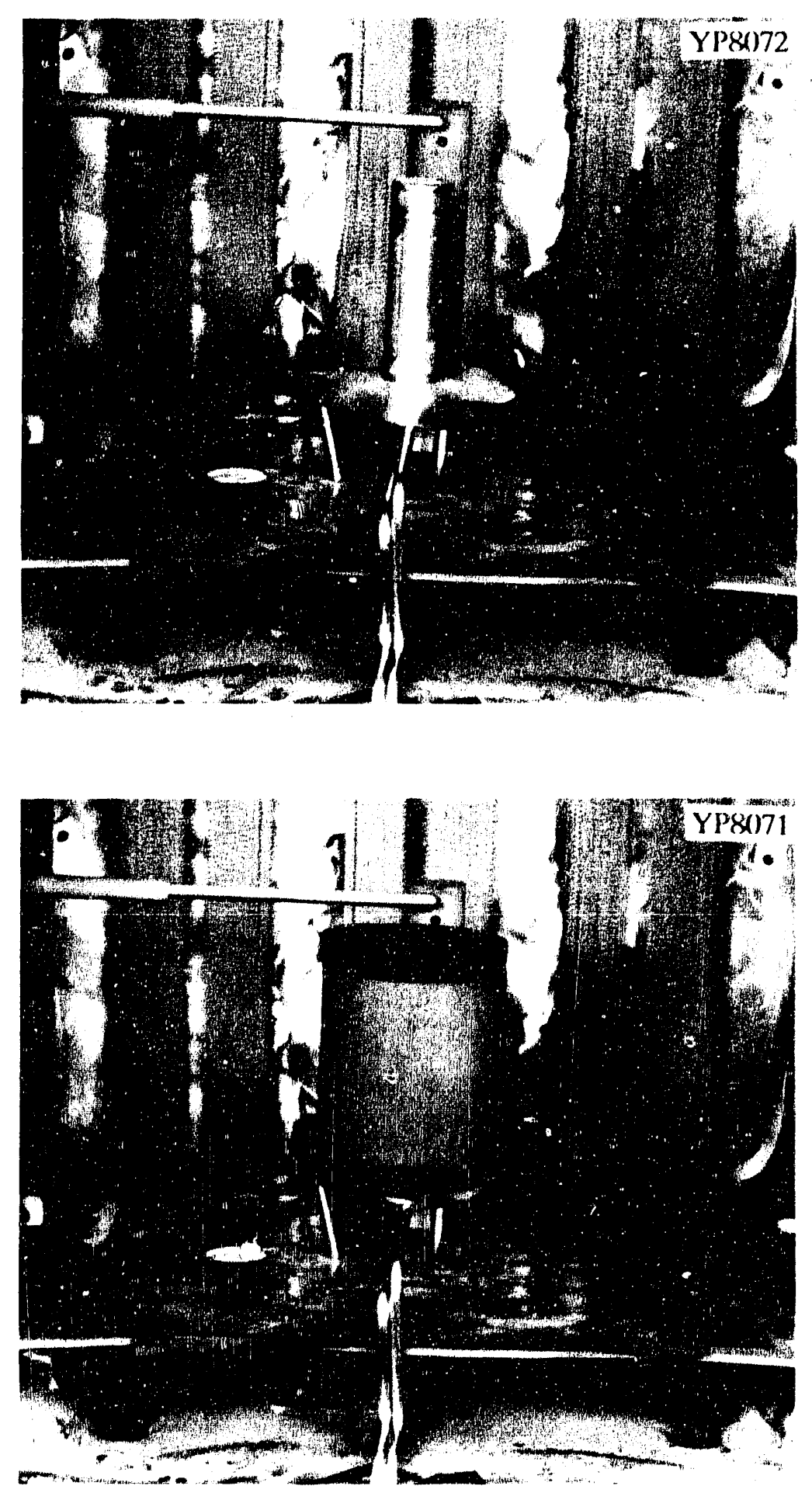

Fig. 3. Interior of vacuum furnace, showing cold finger used to cool the inside diameter of the prototype capsule during thermal cycling. Top: cold finger (note test capsule behind it on the right). Bottom: prototype capsule in place, with C. CF insulation above and below it. 


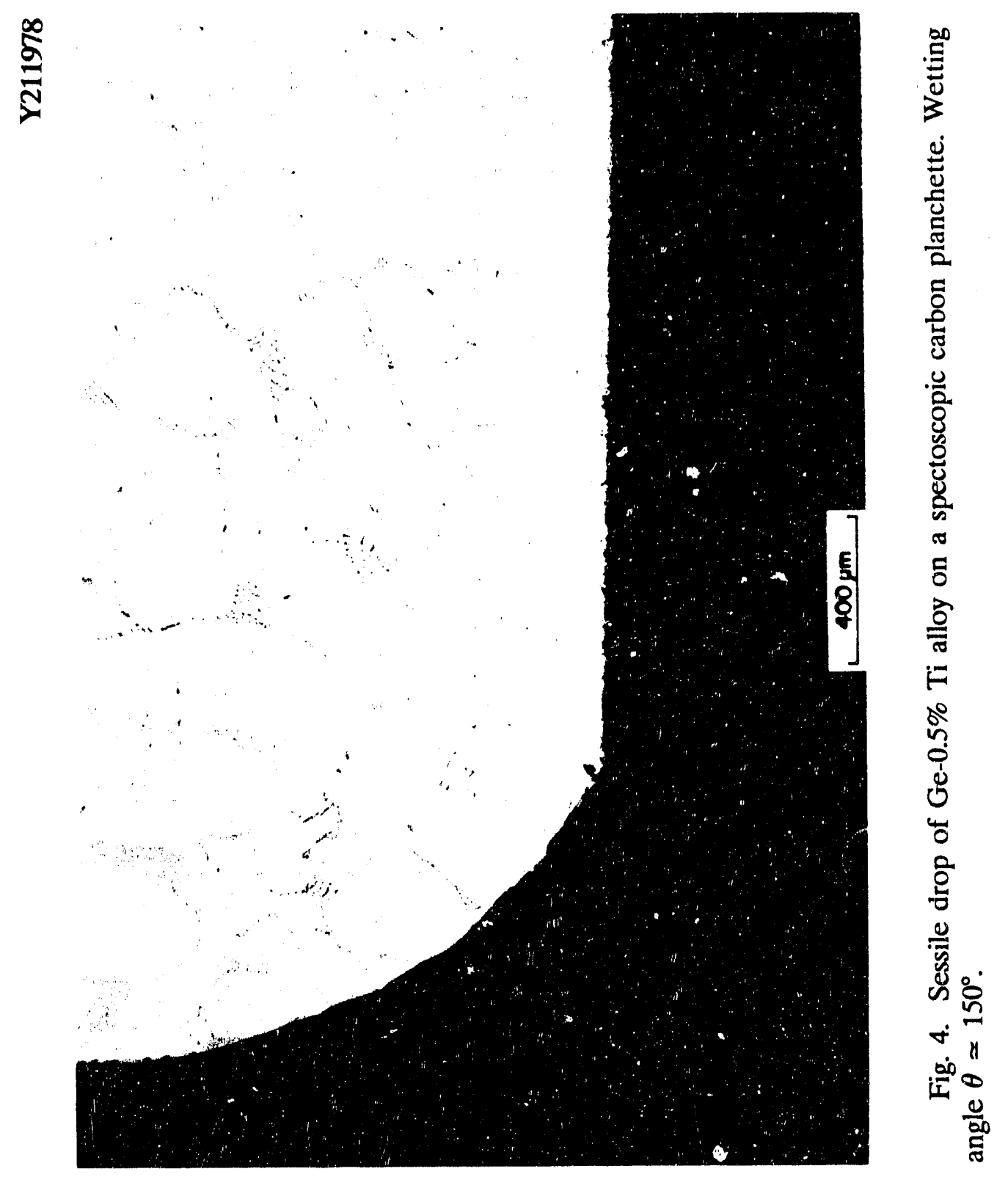


욯

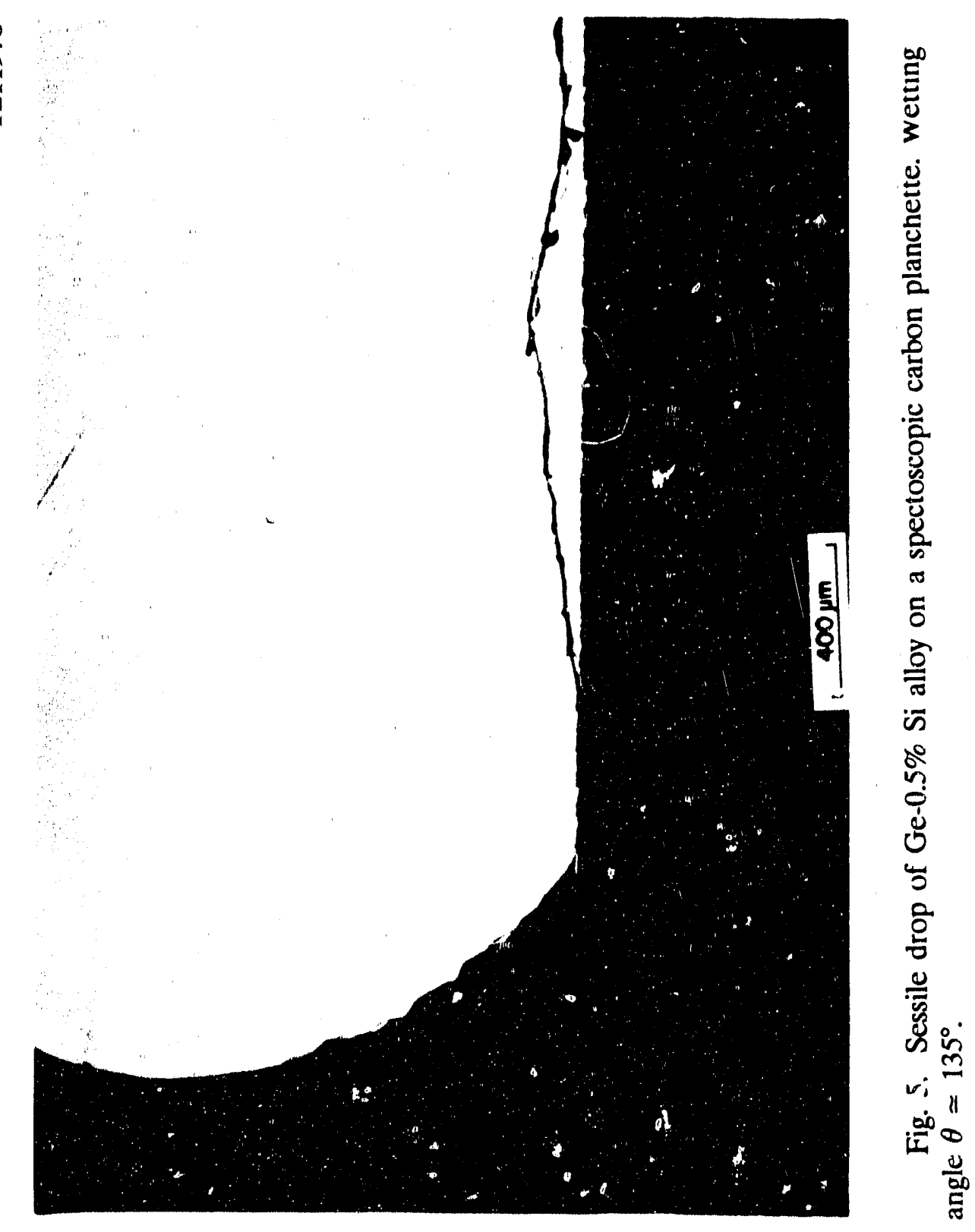


on cooling to ambient the metal was able to slide freely within the capsule. To test the adey $y_{\text {acy }}$ of the threaded closure, the Grade 1 capsule was turned upside-down from cycles 56 through 89. No Ge leaked from the capsule, but a small amount became trapped in the innermost thread. Because of abrasion at that point during later openings, this capsule showed slightly higher weight losses than the others. This capsule is still intact after 544 cycles. The Grade 2 capsule cracked around the bottom after 544 cycles, but no Ge escaped.

An interesting feature of pure $\mathrm{Ge}$ is expansion on freezing, which leads to an upwelling of material at the top of the capsule (under normal gravity). This structure (Fig. 6) is nothing more than the inverse of the shrinkage cavity one normally observes at the top of a solidified metai ingot, but it serves to illustrate that expansion occurs on freezing, and any engineering design must accommodate it. Furthermore, one must recall that in a microgravity erivironment it becomes difficult to predict the locations of solid and liquid; yet for the capsule to survive, the liquid must always be free to communicate with the void space.

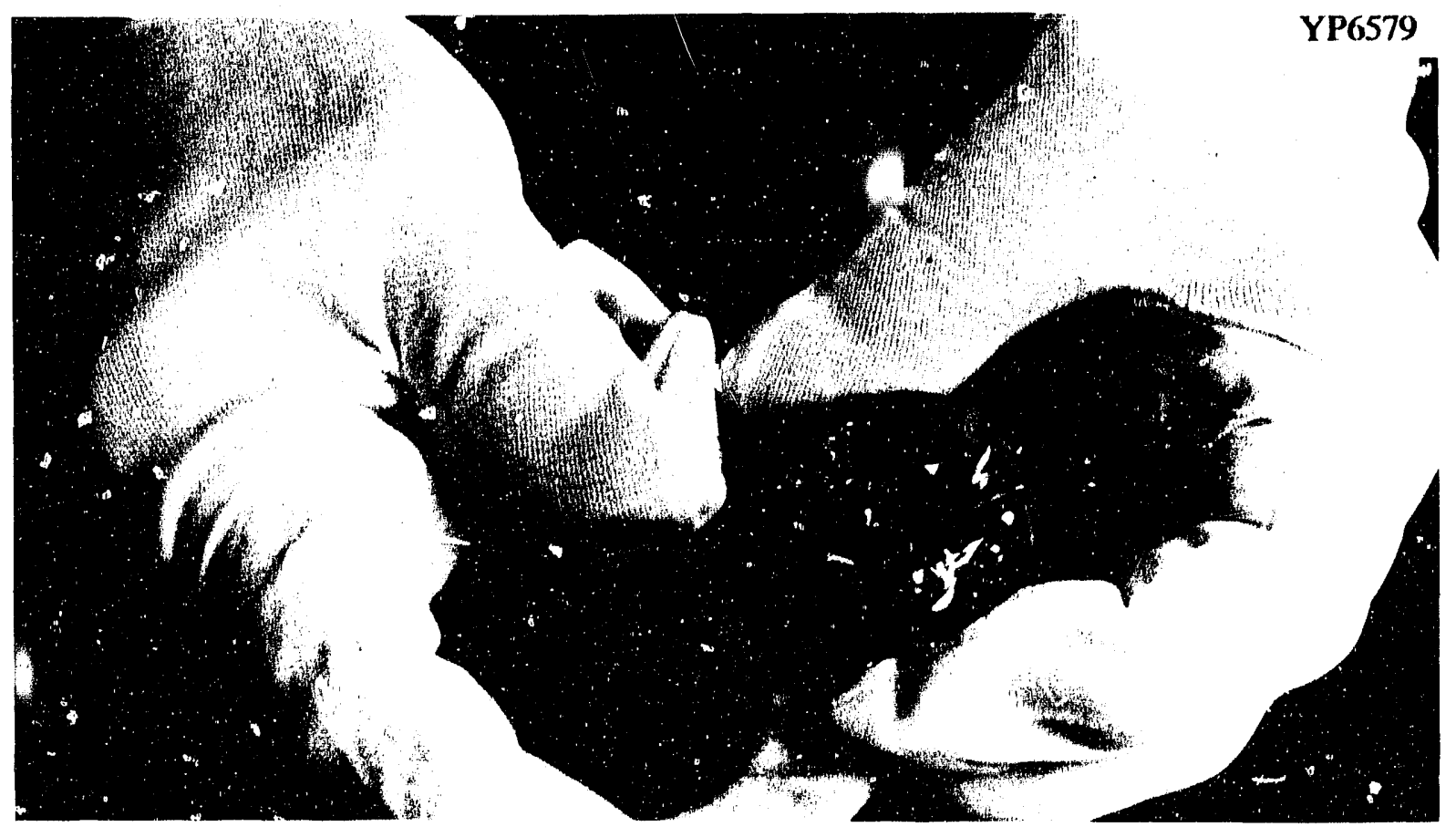

Fig. 6. Test capsule containing pure Ge, showing structure that forms by expansion of the Ge upon solidification. 
The Ge- $0.5 \%$ Ti alloy in a Grade 1 capsule showed some wetting during the early cycles. Later, wetting decreased, and the alloy developed a granular surface. We attributc this to loss of $\mathrm{Ti}$ from the melt through formation of TiC particles. A Grade 2 capsule with somewhat more PCM of this composition cracked after 52 cycles.

The Ge- $0.5 \%$ Si alloy in a Grade 1 capsule showed some wetting of the graphite, which increased steadily with further cycing. After 544 cycles, the meniscus was nearly $5 \mathrm{~mm}$ above the bulk of the melt. A Grade 2 sapsule that contained a larger quantity of this alloy cracked after 52 cycles. This failure, like the previous two, appeared to originate at the inside corner in the bottom of the capsule. This sugge ts that a l. rger radius could help decrease the stress concintration and possibly prevent these failures. It is also interesting to note that all three failures were Grade 2 material.

Altho'gh difficult to quantify (given the irregular shapes involved), it appears that neither of the Ge alloys expand as much on freezing as does pure Ge. This cbservation might be sigrificant, because volume changes on freezing, if constrained, give rise to essentially irresistible forces that must be avoided in service.

An empty Grade 1 capsule was tested with the others to see how much weight loss can be attributed to graphite oxidatiun (due to residual gases) as opposed to PCM evaporation or leckage. Representative weight loss data (Fig. 7) show that almost all of the observed loss was accounted for by graphite oxidation. Note that absolute weight losses were used rather than relative (percent) losses, because they better illustrate this fact. Under these corditions, a capsule containing mo:e metal would a ppear to show a lower percentage weight loss, obscuring the underlying phenomenon.

\subsubsection{Priotype Capsules}

A prototype capsule of the "hullow annulus" geometry m.ade from Stackpole 2020 (Grade 1) that contained about $750 \mathrm{~g}$ Ge was tested for 482 cycles. The capsule remained intact but lost some Ge through seepage along the inside diameter, leading to large weight losses (Fig. 8). A similar capsule made from POCO AXF-5Q showed no Ge leakage and much iower weight loss than even the small Stackpole test capsules, indicating a very low rate of graphite oxidation for the AXF-5Q. The POCO capsule was tesied for 358 cycles without furced cooling and an additional 44 cycles with the cold finger in place. These tests are continuing. Note that both of these capsules have two radial CBCF shims 
ORNL-DWG 90-13966

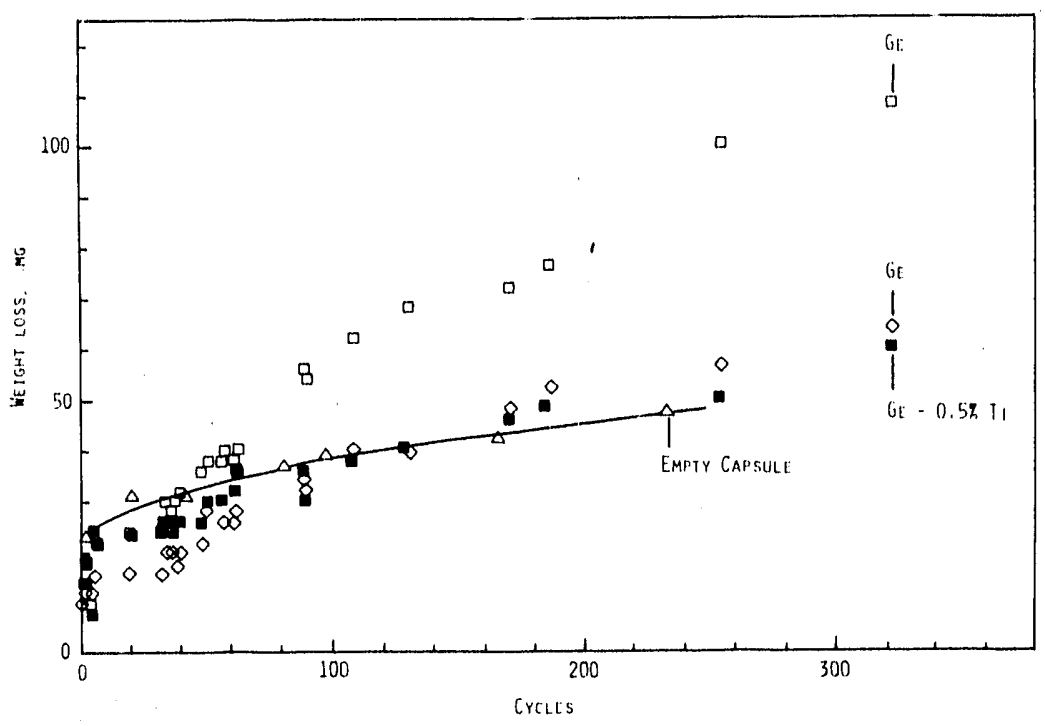

Fig. 7. Weight loss data for several test capsules. Each cycle consists of $1 \mathrm{~h}$ at $773 \mathrm{~K}$ and $2 \mathrm{~h}$ at $1273 \mathrm{~K}$. The weight loss from an empty graphite capsule (curve with cpen triangles) represents the weight loss caused by graphite oxidation. Anomalous losses from one Ge sample were the result of metal adhesion to the threaded ciosure.

ORNL-DWG 90-13967

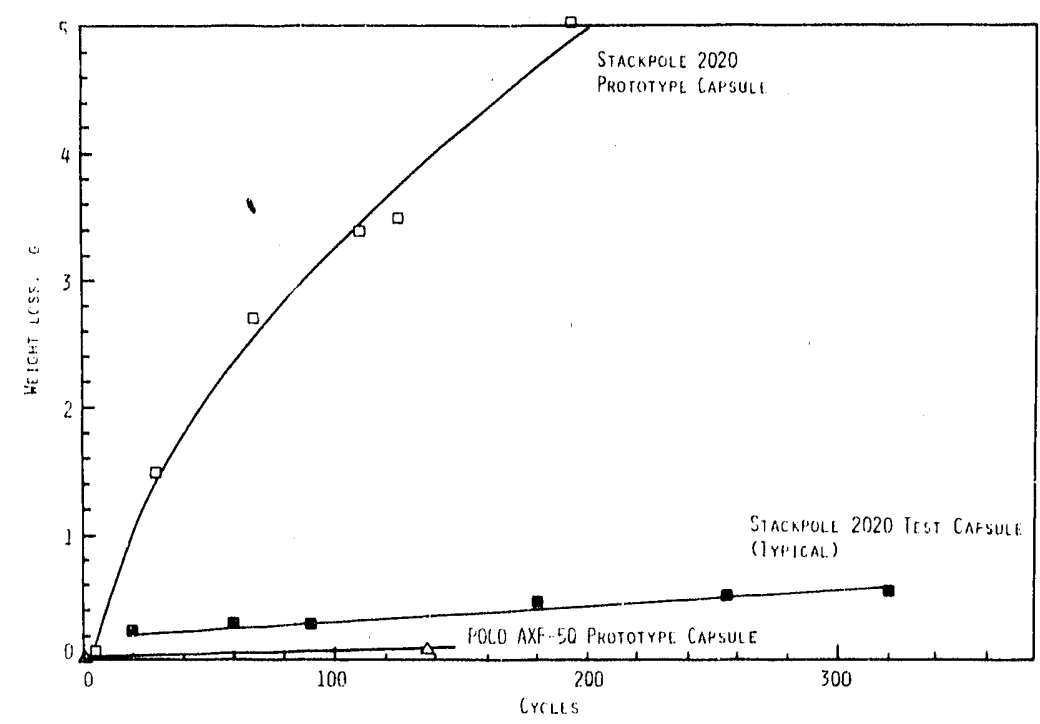

Fig. 8. Weight loss data for two prototype capsules containing $\mathrm{Ge}$ and for one empty test capsule. The weight loss from the 2020 prototype capsule was mainly the result of Ge loss by seepage. The loss from the test capsule represents graphite oxidation. Weight losses from the POCO AXF-5Q prototype capsule were extremely low. 
running lengthwise in the cavity to divide the PCM into two D-shaped segments. This provides enough compliance to accommodate the different coefficients $\mathrm{c}_{-}$thermal 'xpansion (CTEs).

Prototype capsules of the "drilled cavities" geometry, both 2020 and AXF-5Q, were tested with germanium, and each capsule fractured on the inside :iameter after three cycles. Examination of the metal PCM showed that it had frozen on the top and bottom, leaving trapped liquid in the center of the cavity. The expansion that occurred when this liquid froze broke through the capsule wall. It is possible that directional solidification control with the cold finger could eliminate this failure mode; however, it is not clear that the drilled geometry conveys any special benefits. (The original motivation to test this geometry involved greater compartmentalization of the PCM and possibly simpler mass production. It does, however, hold less Ge than the hollow annulus, so the parasitic mass is greater.) Because of the greater difficulty in preventing trapped liquid, this design is of limited interest for further development.

Table 5 compares the characteristics of germanium/graphite thermal storage modules (hollow annulus type) from the present work with those of the molten salt/superalloy system. ${ }^{1}$ In addition to the improved storage capacity, the Ge/graphite assembly is easier to fabricate and much more tolerant of temperature excursions above the melting point of the PCM. No attempt has been made to optimize the design to minimize the parasitic mass of graphite, so further development work should lead to improved performance.

Table 5. Comparison of heat storage systems

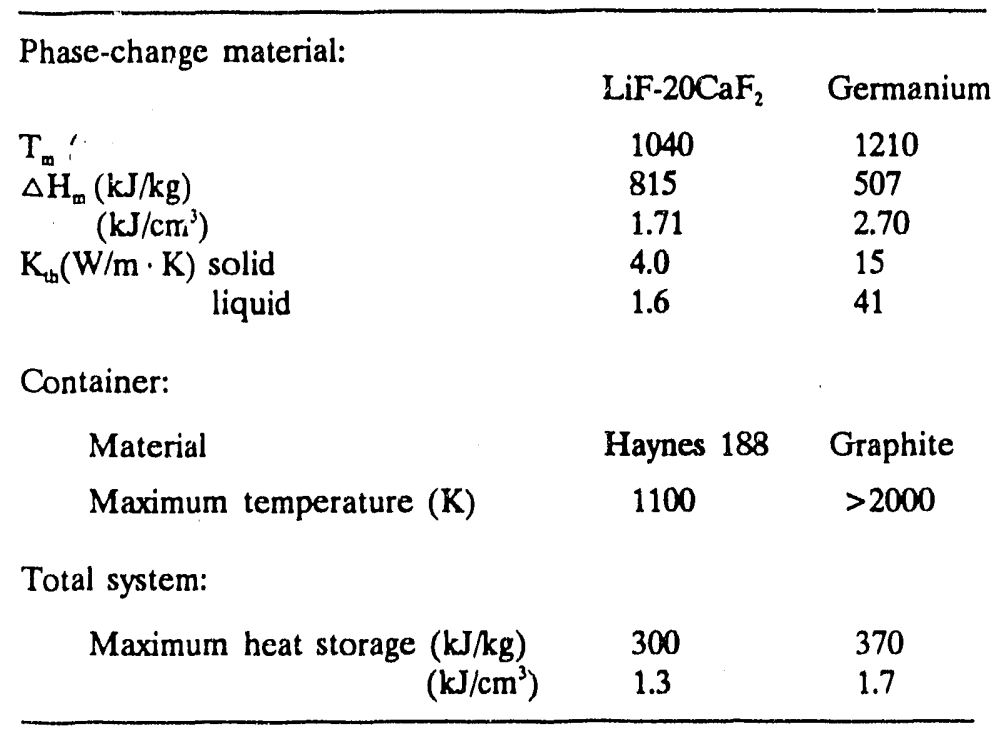


Crane and Bharadhwaj ${ }^{7}$ recently modeled the perfurmance of several heat receiver concepts in solar-powered Brayton and Stirling engines. They compared $\mathrm{LiF}-22 \mathrm{CaF}_{2}$ salt, several "enhanced" salts containing BN or pyrolytic carbon foams for better thermal conductivity, and pure Ge. Their calculations show that the high thermal conductivity of the Ge PCM "virtually eliminates all thermal variation" in the Stirling heat pipe receiver.

\section{$2.2 \mathrm{Mg}_{2} \mathrm{Si}-\mathrm{Si}$ EUTECTIC}

The $\mathrm{Mg}-\mathrm{Si}$ system ${ }^{8}$ contains the compound $\mathrm{Mg}_{2} \mathrm{Si}$, which melts at $1375 \mathrm{~K}$. On either side of this line compound are two simple eutectics. The $\mathrm{Mg}-\mathrm{Mg}_{2} \mathrm{Si}$ eutectic occurs at $911 \mathrm{~K}$ and 1.34 wt \% Si. The $\mathrm{Mg}_{2} \mathrm{Si}-\mathrm{Si}$ eutectic occurs at about $1223 \mathrm{~K}$ and $58 \mathrm{wt} \% \mathrm{Si}$. The latter composition is the alloy of interest here as a PCM.

The $\mathrm{Mg}_{2} \mathrm{Si}$-Si eutectic composition cannot be made at reasonable pressures by melting a mixture of the pure elements. This is because of the large difference in melting points. At the melting temperature of $\mathrm{Si}(1703 \mathrm{~K})$, vaporization losses of $\mathrm{Mg}$ would be excessive; therefore, we were limited to forming the eutectic in situ by mixing $\mathrm{Si}$ chips and $\mathrm{Mg}_{2} \mathrm{Si}$ powder in the test capsules and melting at $1273 \mathrm{~K}$. For this reason, the $\mathrm{Mg}_{2} \mathrm{Si}-\mathrm{Si}$ eutectic was not available in a form suitable for the sessile drop test.

\subsubsection{Test Capsules}

A Grade 2 Stackpole 2020 test capsule was filled with $\mathrm{Mg}_{2} \mathrm{Si}$ powder and Si chips. After $2 \mathrm{~h}$ at $1273 \mathrm{~K}$, the charge had melted thoroughly and settled in the capsule. More material was added and remelted at $1273 \mathrm{~K}$. After the second melting, the lid adhered to the capsule and could not be unscrewed. After the third cycle, there was a small crack running about halfway around the capsule near the bottom. The test was concluded, and the capsule was sectioned lengthwise for metallographic examination. From the micrographs (Figs. 9 and 10), it is clear that this alloy readily wets graphite $\left(\theta \simeq 0^{\circ}\right)$. After only three cycles the meniscus had climbed to the top of the capsule. A reaction zone is about $100 \mu \mathrm{m}$ deep, characterized by penetration of metal nodules and some restructuring of the graphite. If the apparent densification of the graphite in this region represents formation of $\mathrm{SiC}$ in the pore spaces, penetration could possibly be self-limiting. Otherwise, it will be necessary to protect the graphite from attack by applying a chemically vapor deposited (CVD) coating of $\mathrm{SiC}$ or a similar material. Before that option is 
Y211974

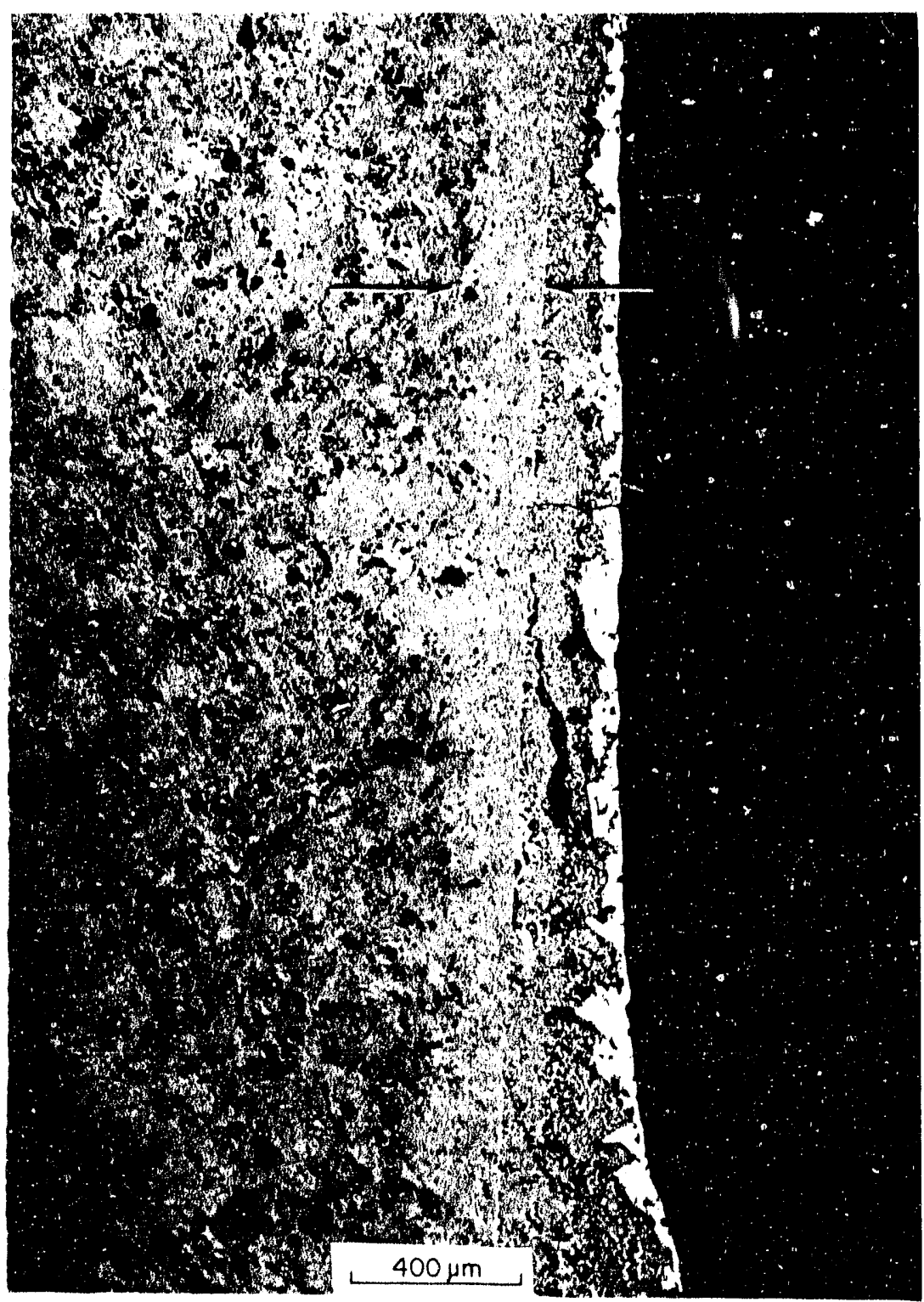

Fig. 9. $\mathrm{Mg}_{2} \mathrm{Si}-\mathrm{Si}$ eutectic alloy forming a thin meniscus on the inner surface of a Stackpole 2020 test capsule. Note restructured layer in the graphite (arrows). 
$\frac{n}{5}$

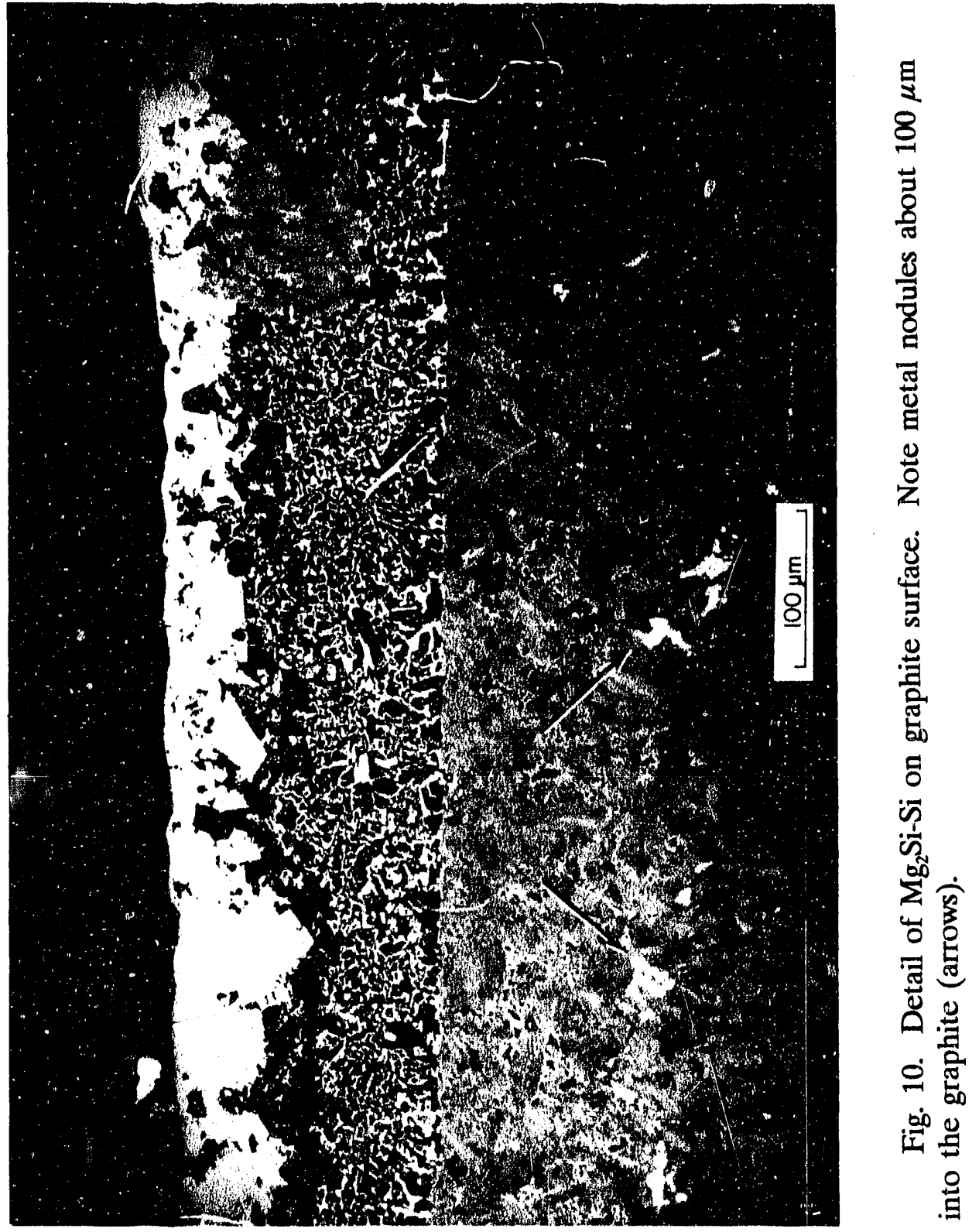


explored, test capsules will be machined from POCO graphite to see if the attack can be eliminated by microstructural control of the graphite.

A Grade 1 Stackpole test capsule containing this alloy cracked after seven thermal cycles. Both of these early failures suggest a thermal expansion mismatch between the $\mathrm{PCM}$ and the graphite. Because the liquid $\mathrm{Mg}_{2} \mathrm{Si}-\mathrm{Si}$ readily wets graphite, this PCM was used to test the infiltration approach for eliminating CTE-driven fracture. These results are discussed later.

\section{$23 \mathrm{NiSi}^{-\mathrm{NiSi}_{2}}$ EUTECTIC}

The Ni-Si system ${ }^{9}$ contains a number of intermediatc phases (at least seven) and numerous invariant reactions. Of interest here is the eutectic NiSi-NiSi, which occurs at $1238 \mathrm{~K}$ and $38 \mathrm{wt} \% \mathrm{Si}$. This alloy is readily made by arc-melting a mixture of the elements in a water-cooled copper hearth. Alternatively, a physical mixture of the elements will melt, with somewhat more difficulty, at temperatures as low as $1273 \mathrm{~K}$ in vacuum. Once melting begins, alloying generally proceeds to completion.

\subsubsection{Sessile Drop}

The sessile drop of arc-melted $\mathrm{NiSi}-\mathrm{NiSi}_{2}$ eutectic on a spectroscopic carbon planchette, held at $1273 \mathrm{~K}$ for $4 \mathrm{~h}$ in vacuum, had a contact angle of about $110^{\circ}$. Metallographic examination (Fig. 11) showed that some metal had penetrated into the carbon planchette. The metal bead was extensively cracked and appeared to have dissolved some carbon, which was rejected as a second phase on cooling. This is consistent with previous observations that certain low-melting nickel and cobalt alloys exhibit remarkably high carbon solubilities in the liquid phase.

\subsubsection{Test Capsules}

$\mathrm{NiSi}-\mathrm{NiSi}_{2}$ appears to have a much lower CTE than graphite. Test capsules containing this alloy invariably fractured on their first cooldown to ambient. At the same time, however, capsules appeared to survive any number of cycles between 773 and $1273 \mathrm{~K}$, because there was no evidence of prior leakage from the broken capsules. (Unlike the $\mathrm{Mg}$-Si capsules that simply developed small cracks, the Ni-Si capsules were catastrophically 


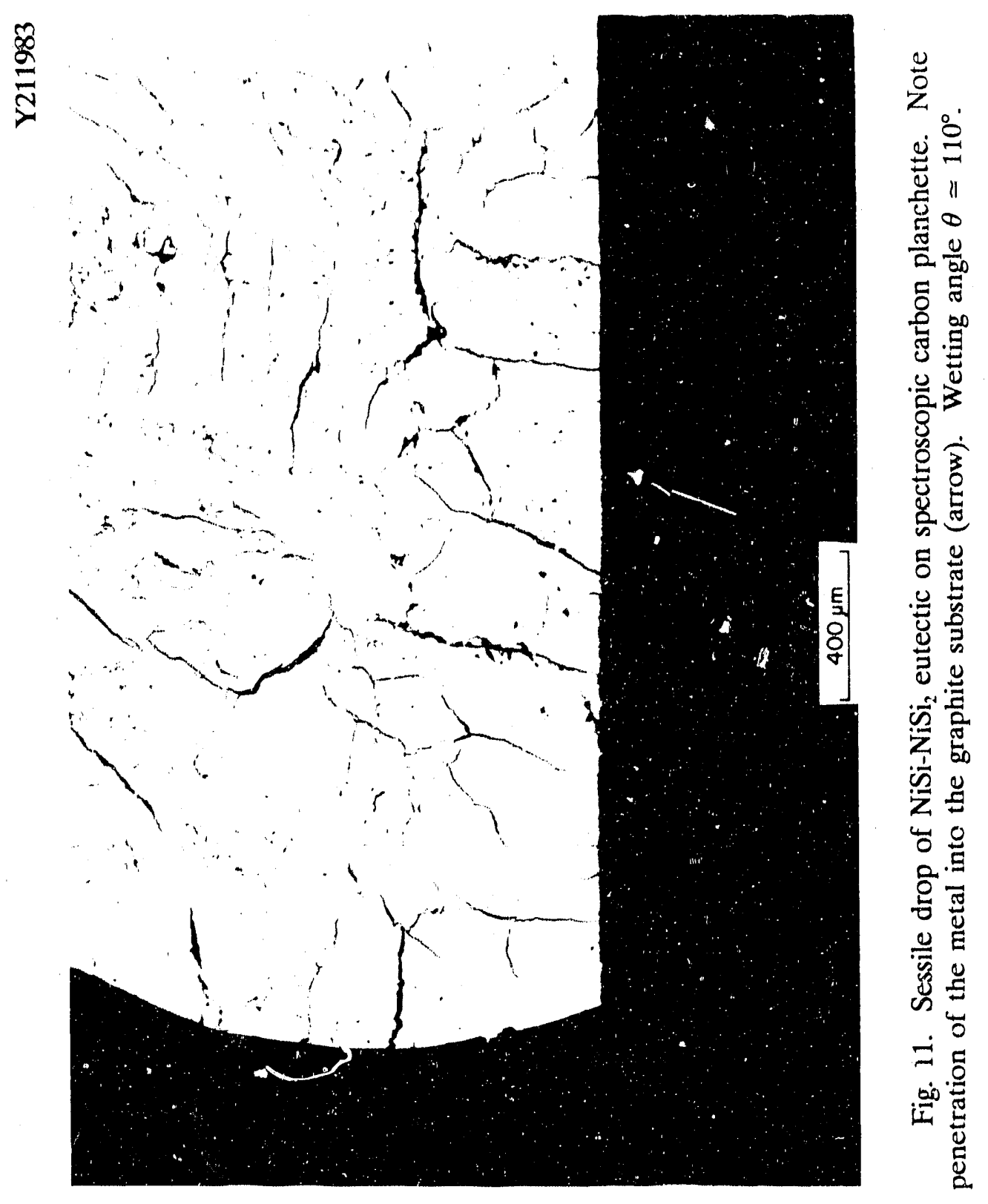


fractured into many pieces on cooldown to ambient. If that fracture had occurred during the run, on later meltings the molten $\mathrm{NiSi}-\mathrm{NiSi}_{2}$ would have run all over the furnace cavity.)

Although some penetration was seen in the sessile-drop test, it is clear that NiSi$\mathrm{NiSi}_{2}$ is not nearly as reactive toward graphite as is $\mathrm{Mg}_{2} \mathrm{Si}-\mathrm{Si}$. On the other hand, the thermal expansion mismatch seems to be greater for this alloy. It is not known at this time whether the CTE of graphite could be reduced enough through microstructural control to make this system physically compatible. Preliminary tests to evaluate infiltration as a means of accommodating this CTE mismatch are reported in the following section.

\section{ADVANCED CONCEPTS}

\subsection{TERNARY EUTECTIC ALLOYS}

We have identified two ternary alloy systems with potentially interesting properties for advanced thermal energy storage systems, namely, Mg-Si-Ge and Ni-Si-Ge. These systems are attractive for the following reasons:

1. Germanium is very benign toward graphite. It is possible that the ternary alloys might combine the attractive thermal properties of the $\mathrm{Mg}-\mathrm{Si}$ or $\mathrm{Ni}-\mathrm{Si}$ systems with the desirable chemical characteristics of Ge.

2. Ternary eutectic systems provide a series of compositions whose individual melting temperatures can be chosen over a wide range, allowing greater latitude in designing the receiver and heat engine.

3. From a design standpoint, the thermal receiver might be more efficient if thermal energy storage modules with slightly different melting temperatures were distributed to eliminate dead spots that never melt or never frceze.

4. Because of the chemical similarity of $\mathrm{Ge}$ and $\mathrm{Si}$, the $\mathrm{Mg}-\mathrm{Ge}$ and $\mathrm{Ni}-\mathrm{Ge}$ phase diagrams ${ }^{10,11}$ are similar to the $\mathrm{Mg}-\mathrm{Si}$ and $\mathrm{Ni}$-Si systems. Thus, the general features of the corresponding ternary systems can be predicted with some confidence.

\subsubsection{The Mg-Si-Ge System}

The $\mathrm{Mg}-\mathrm{Ge}$ system ${ }^{10}$ contains the line compound $\mathrm{Mg}_{2} \mathrm{Ge}$, which melts at $1388 \mathrm{~K}$. The $\mathrm{Mg}_{2} \mathrm{Ge}-\mathrm{Ge}$ eutectic occurs at $953 \mathrm{~K}$ and $82.3 \mathrm{wt} \% \mathrm{Ge}$. Note that $\mathrm{Mg}_{2} \mathrm{Ge}$ is isostructural with $\mathrm{Mg}_{2} \mathrm{Si}$; its lattice parameter $(6.390 \AA)$ is very close to that of $\mathrm{Mg}_{2} \mathrm{Si}(6.351 \AA)$, suggesting that the line compound probably exists for all Go--Si ratios. The Mg-rich side of 
the $\mathrm{Mg}$-Ge binary is virtually identical to that of the Mg-Si system. Based on these similarities, the probable Mg-Si-Ge ternary phase diagram is shown in Fig. 12.

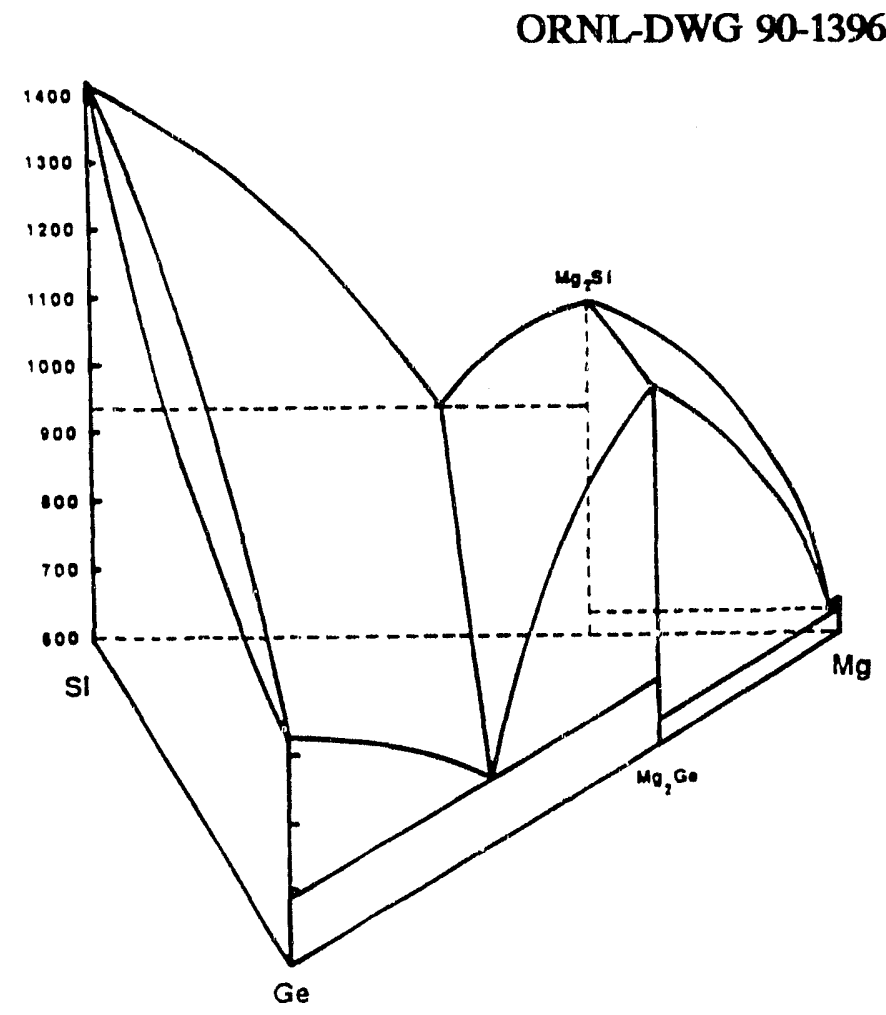

Fig. 12. Postulated Mg-Si-Ge ternary phase diagram, constructed from the respective binaries.

Compositions lying along the eutectic "trough" should have very narrow freezing ranges because they would solidify according to the eutectic reaction

$$
\mathrm{L} \rightarrow \mathrm{Mg}_{2}(\mathrm{Si}, \mathrm{Ge})+\beta
$$

where $\beta$ is a Ge-Si solid solution.

As the first step toward characterizing the ternary system, Ge chips, Si chips, and $\mathrm{Mg}_{2} \mathrm{Si}$ powder were mixed in a test capsule and melted at $1373 \mathrm{~K}$. The composition was intentionally Ge-rich ( $\mathrm{Ge}: \mathrm{Si}=4: 1$ ) and $\mathrm{Mg}$-poor so that the first solid to appear on freezing should be Ge-Si solid solution. The liquid composition would then follow the eutectic trough shown in Fig. 12 and solidification would end with a reaction close to

$$
\mathrm{L} \rightarrow \mathrm{Mg} \mathrm{Ge}+\mathrm{Ge} .
$$


The microstructure of this alloy (Fig. 13), along with qualitative energy dispersive $\mathrm{X}$-ray analysis (EDX), confirms the general features of this alloy system. Proeutectic dendrites have a Si-rich core surrounded by more Ge-rich solid solution, as one would expect if freezing is too fast to allow homogenization in the solid phase. The interdendritic phase contains virtually no $\mathrm{Si}$, as expected. (Note that EDX analysis is complicated by overlap of $\mathrm{Ge} \mathrm{L} \alpha$ and $\mathrm{Mg} \mathrm{K} \alpha$ lines. One can surmise the presence of $\mathrm{Mg}$ qualitatively by noting the relative intensities of $\mathrm{Ge} L \alpha$ and $\mathrm{K} \alpha$ lines.)

Further characterization of this alloy system should yield eutectic alloys with any desired melting point from 953 to $1213 \mathrm{~K}$ and large heats of fusion.

\subsubsection{The Ni-Si-Ge System}

Because the $\mathrm{Ni}-\mathrm{Si}$ and $\mathrm{Ni}-\mathrm{Ge}$ binary systems are so complex, it is not possible to construct the ternary diagram $a$ priori. However, consideration of the binaries ${ }^{9,11}$ suggests that a range of compositions running approximately from the $\mathrm{NiSi}-\mathrm{NiSi}_{2}$ eutectic to the

\section{L1838}

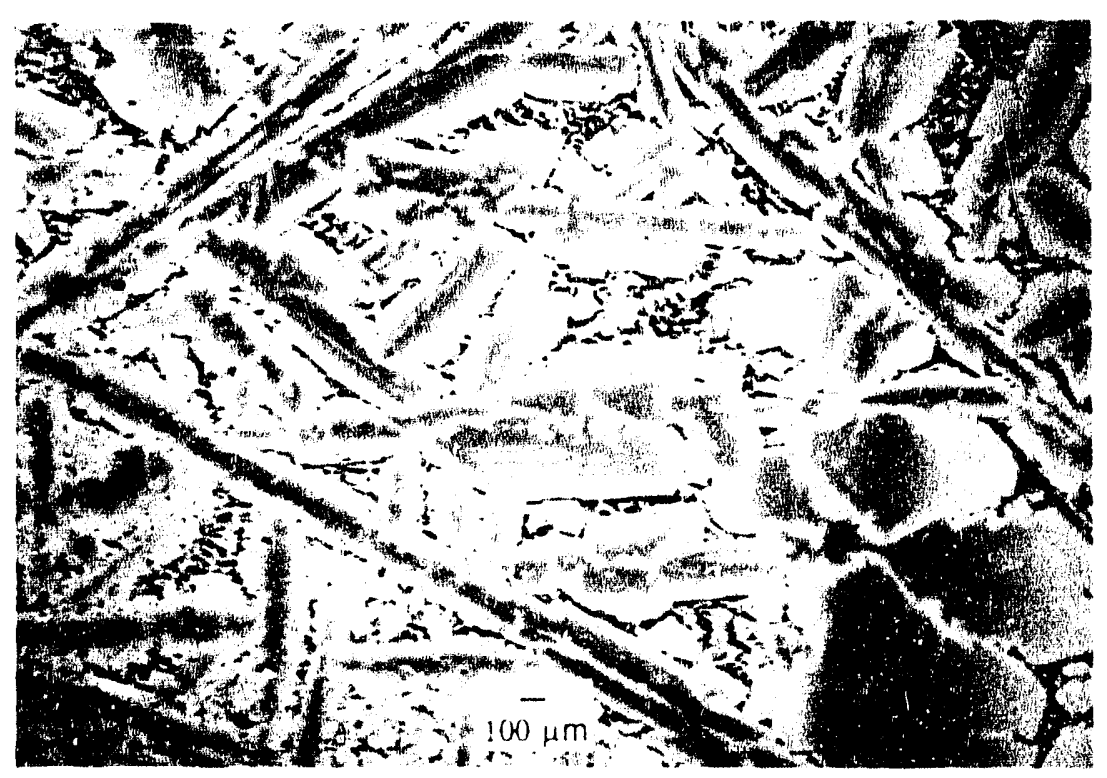

Fig. 13. Mg-Si-Ge alloy melted at $1373 \mathrm{~K}$ and furnace cooled. Microstructure consists of cored dendrites of Ge-Si solid solution surrounded by a Si-poor eutectic approximated by $\mathrm{Mg}_{2} \mathrm{Ge}+\mathrm{Ge}$. 
NiGe-Ge eutectic should yield relatively narrow melting points ranging from 1035 to $1239 \mathrm{~K}$. Actual predictions are complicated by the fact that the compound $\mathrm{NiSi}_{2}$ has no analog in the Ni-Ge system. Future work will include experimental characterization of the Ni-poor region of this ternary system, including thermal and microstructural analysis.

\subsection{INFILTRATION TO CONTROL MELT GEOMETRY}

It is well recognized that the long-term reliability of any PCM system depends on the ability to control the location of solid, liquid, and void within the individual PCM canisters. In the case of fluoride salts, the large volume change on melting implies a large void volume in the solid, which could lead to local hot spots during melting. Cotton and Sedgwick ${ }^{12}$ describe the use of metal felt, which not only controls void distribution but also enhances thermal conductivity.

For our metallic PCMs, infiltration, or "wicking," has two main purposes. First, by controlling void distribution, one can avoid trapping liquid, which would catastrophically expand on freezing. Second, a carefully shaped wick could possibly maintain an appropriate gap to accommodate differential thermal expansion between the solid PCM and the graphite container. Another possible benefit (speculative at this time) is the distribution of nucleation sites throughout the PCM to help it freeze uniformly and to eliminate undercooling.

The wicking concept was tested on $\mathrm{Mg}_{2} \mathrm{Si}-\mathrm{Si}$ and $\mathrm{NiSi}-\mathrm{NiSi}_{2}$ eutectics because these alloys consistently broke their graphite containers (presumably from CTE mismatch) and both wet graphite readily. Two porous media were used as the wicks: CBCF insulation and reticulated carbon foam.

The CBCF material ${ }^{13}$ is made from chopped rayon tiber, which is carbonized and bonded with phenolic resin particles. $\mathrm{CBCF}$ shapes are made by vacuum molding from a water slurry, followed by drying and curing. Final carbonization of the resin is ane at $1873 \mathrm{~K}$. The resulting material has a nominal density of $0.2 \mathrm{~g} / \mathrm{cm}^{3}$. It can be molded into simple shapes or into large plates from which smaller pieces can be cut with a sharp knife. Figure 14 shows the microstructure of a small $\mathrm{CBCF}$ preform before exposure to molten PCM. 

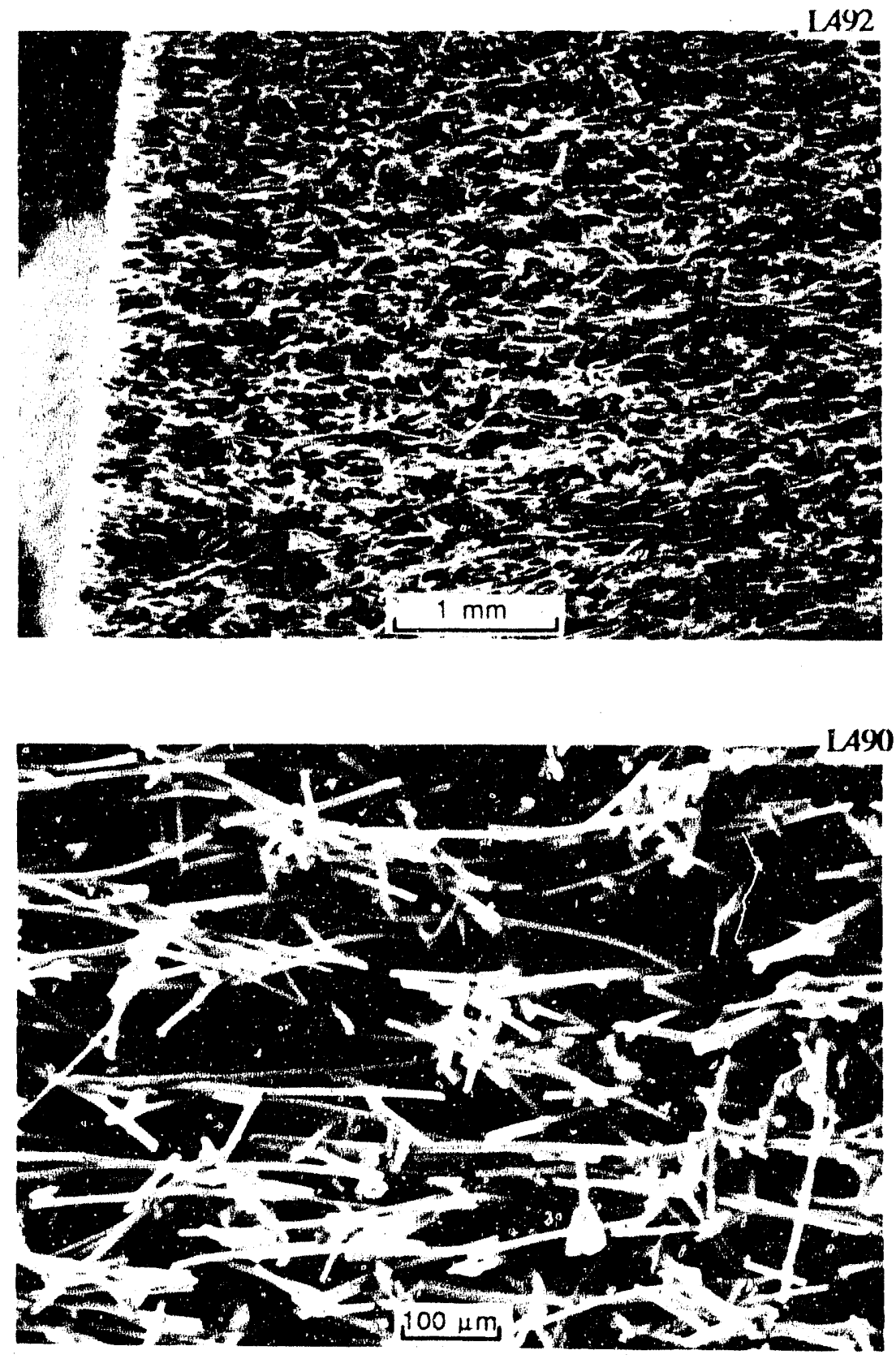

Fig. 14. Scanning electron micrographs of low-density CBCF composite. Top: general structure at $20 \times($ bar $=1 \mathrm{~mm}$ ). Bottom: detail showing fiber arrangement at $100 \times($ bar $=100 \mu \mathrm{m})$. 
CBCF was infiltraied with $\mathrm{Mg}_{2} \mathrm{Si}-\mathrm{Si}$ eutectic by placing a thin slab vertically in the center of a Grade 2 Stackpole 2020 test capsule and surrounding it with $\mathrm{Mg}_{2} \mathrm{Si}$ powder and Si chips. After three cycles, although the charge had not fully seitled and alloyed together, the eutectic that formed was drawn up into the CBCF. All expansion on freezing was then directed into the open space on either side of ine wick (Fig. 15). This capsule is intact after 300 normal cycl ss as weil as one intentional excursion to $1473 \mathrm{~K}$.

Several larger preforms (cylinders and rectangular prisms) were cut from a CBCF plate; these were just small enough to fit inside a test capsule. These preforms were placed in a zirconia crucible, surrounded by $\mathrm{Ni}$ and $\mathrm{Si}$ (both powder and chips), and melted in vacuum at $1473 \mathrm{~K}$. Samples held for $2 \mathrm{~h}$ at $1473 \mathrm{~K}$ were partially infiltrated by the NiSi$\mathrm{NiSi}_{2}$ eutectic. Samples held $3 \mathrm{~h}$ at $1573 \mathrm{~K}$ appeared to be completely infiltrated (Fig. 16). The infiltrated wicks are ready to be placed into test capsules for thermal cycling. Results of these test: will be reported later.

Carbon foam (Fig. 17) is made from a mixture of phenyl-furfuryl alcohol and urethane resin. These components are mixed in water with curing and blowing agents and cast into foam. The urethane resin is sufficiently viscous to support the foam structure, serving as a vehicie for the phenyl-furfuryl component. Heating to 1273 to $1573 \mathrm{~K}$ in argon or nitrogen burns off the urethane and carbonizes the phenyl-furfuryl alcohol. The resulting glassy carbon foam is graphitized at $2273 \mathrm{~K}$.

The graphitized foain has a bulk density of 0.2 to $0.3 \mathrm{~g} / \mathrm{cm}^{3}$ (about $10 \%$ theoretical density). There is a high degree of interconnectivity between the individual pores, although not every pore is directly accessible to each of its neighbors.

As the first step toward full infiltration tests, the ability of $\mathrm{NiSi}-\mathrm{NiSi}_{2}$ to wet carbon form was evaluated by placing chunks $(\sim 1 \mathrm{~cm})$ of the alloy on top of a $3 \times 4 \times 1 \mathrm{~cm}$ thick carbon-foam block. After several 2 -h meltings at $1573 \mathrm{~K}$ in vacuum, the block became progressively more silvery. Scanning electron microscopy (Fig. 18) shows that the alloy penetrated throughout the pore spaces by wetting the surface of the carbon foam. Work will continue on this promising system in order to make samples with a much higher PCM loading for thermal-cycle testing. 


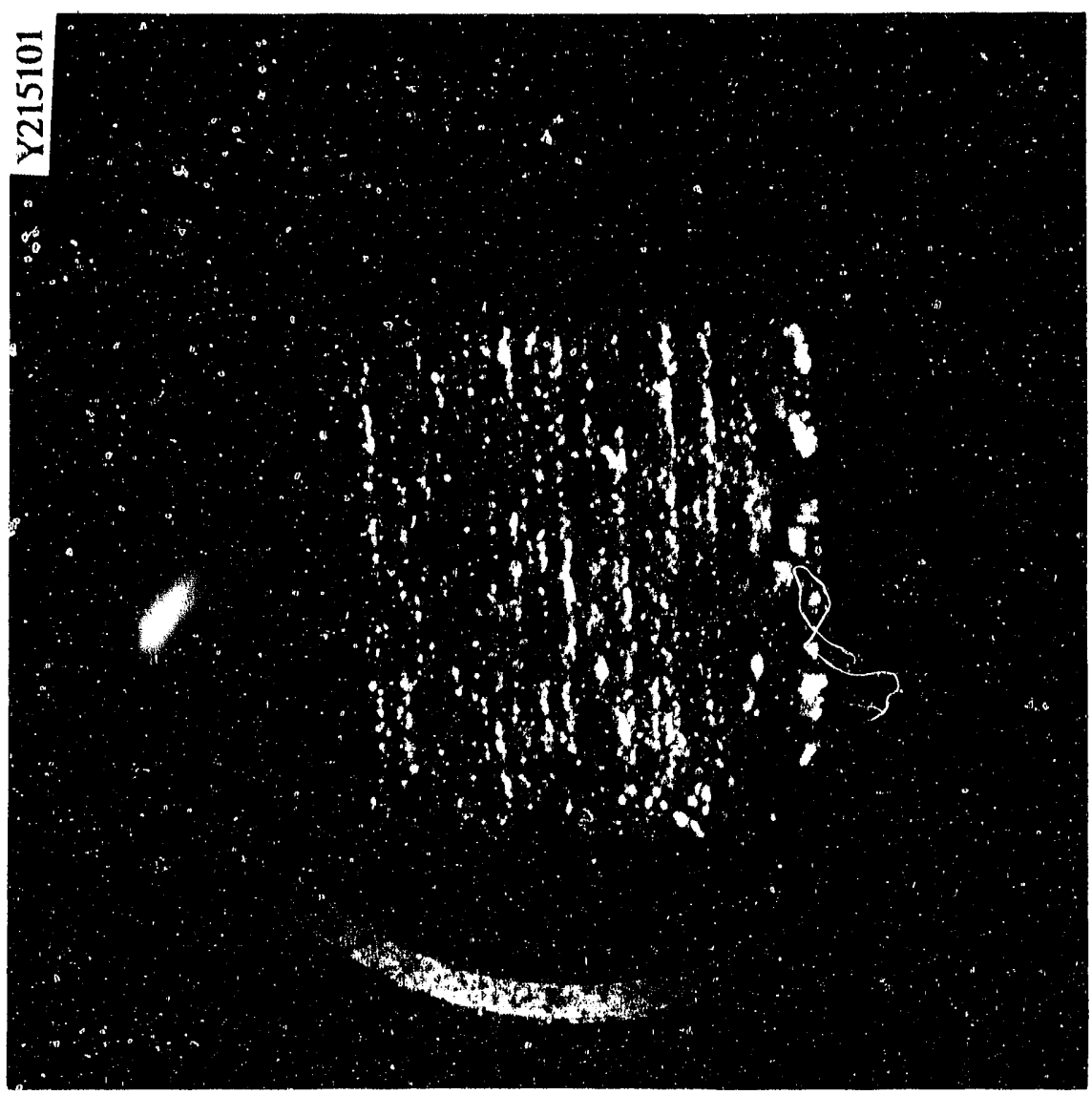

园号

岂

U

卷

용

Ð

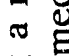

os

.

苞

ठ

जू

总总

4

H

业

후

舟导

证焉

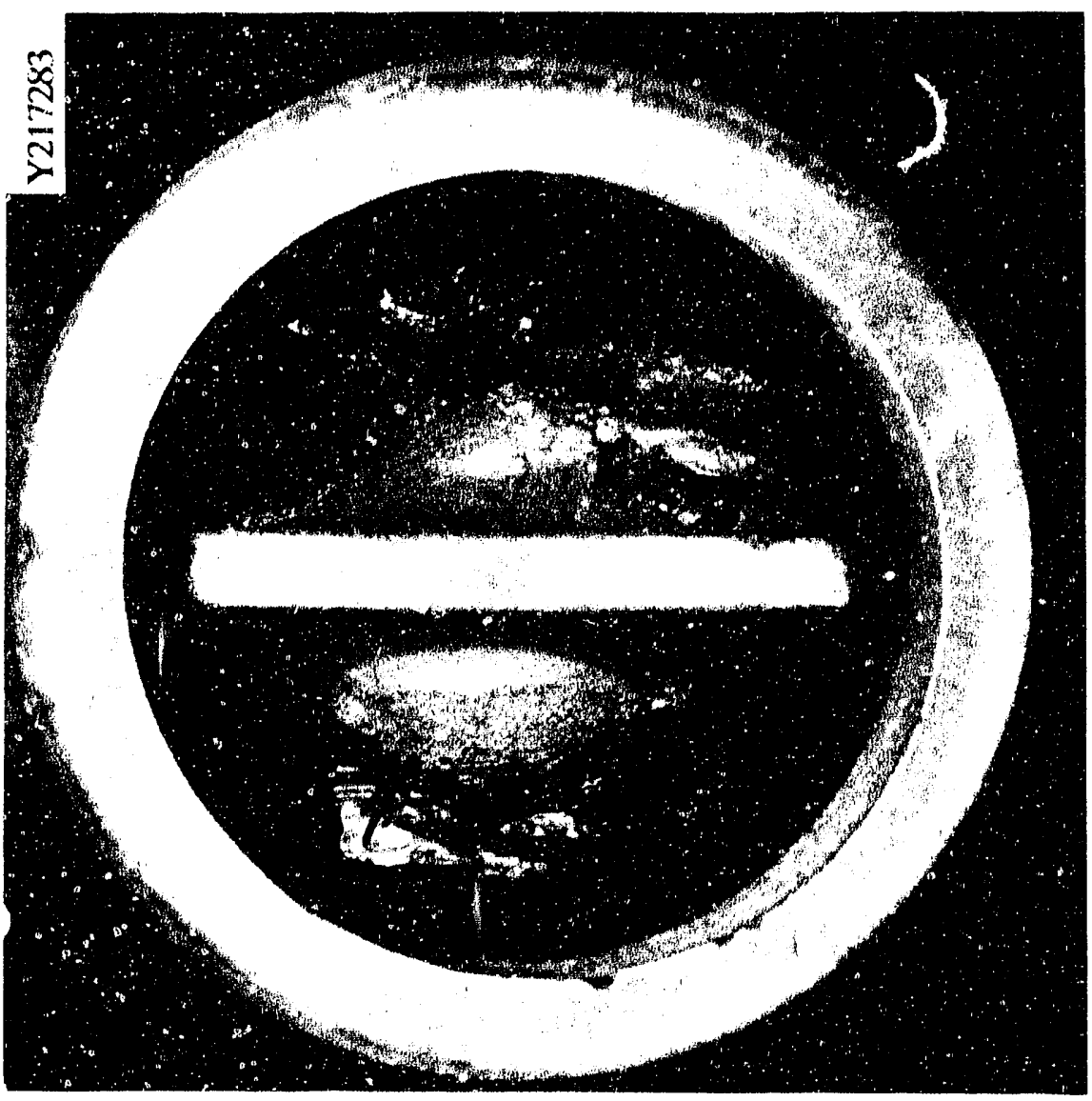

ํㅗㄹ

.

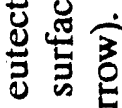

is

论次

$\sum^{\infty}$

$\sum_{\infty} \mathrm{z}$

.

듕의

㟧色

ธ。

웡롱

岁宁

-

ง

$\rightarrow$ 음

os

的告

敦量 

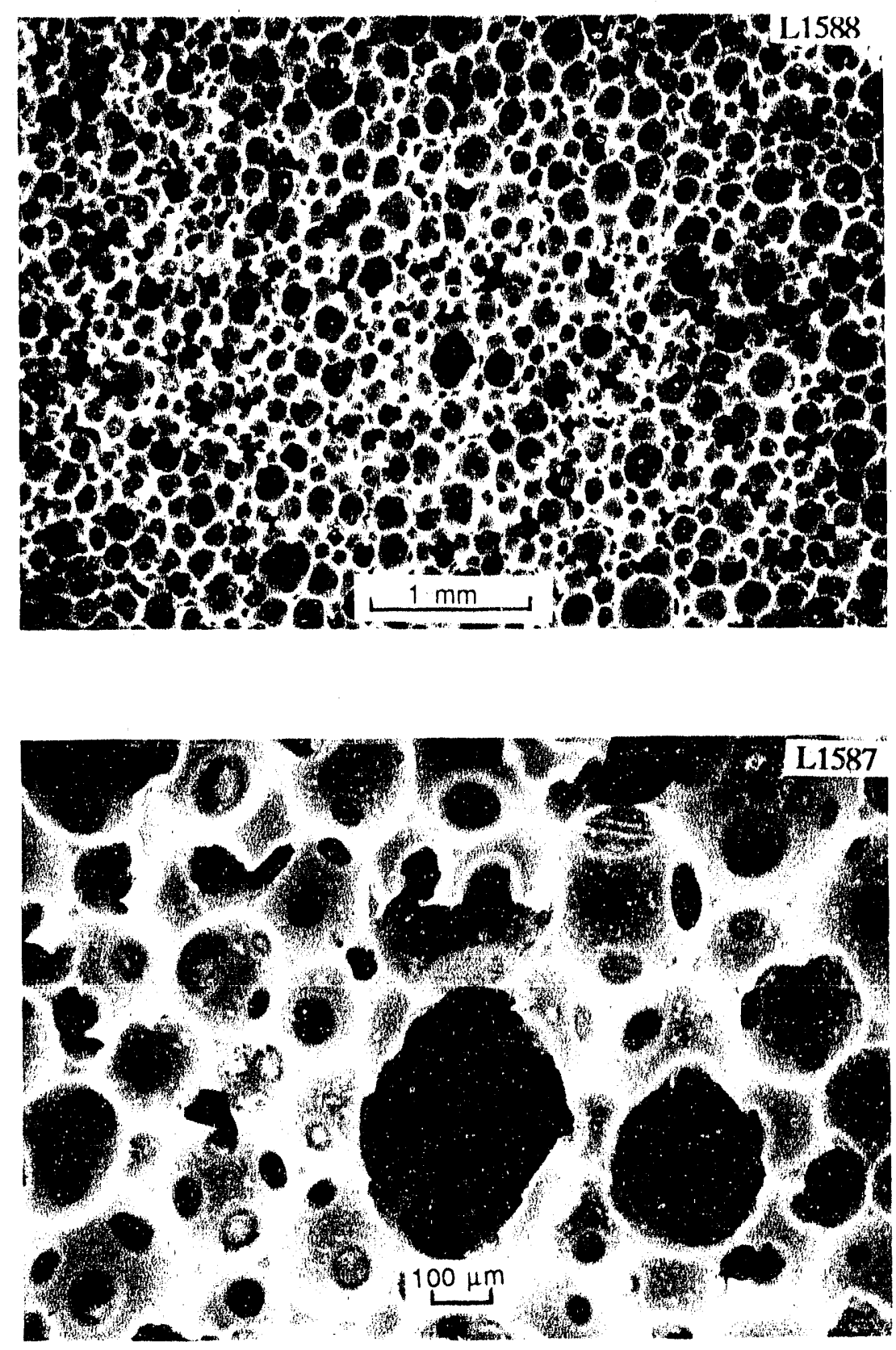

Fig. 17. Scanning electron micrographs of carbon foam. Top: overview of structure at $19 \times$ showing distribution of void diameters (bar $=1 \mathrm{~mm}$ ). Bottom: detail showing open passages $(\sim 50 \mu \mathrm{m})$ between voids at $80 \times($ bar $=100 \mu \mathrm{m})$. 

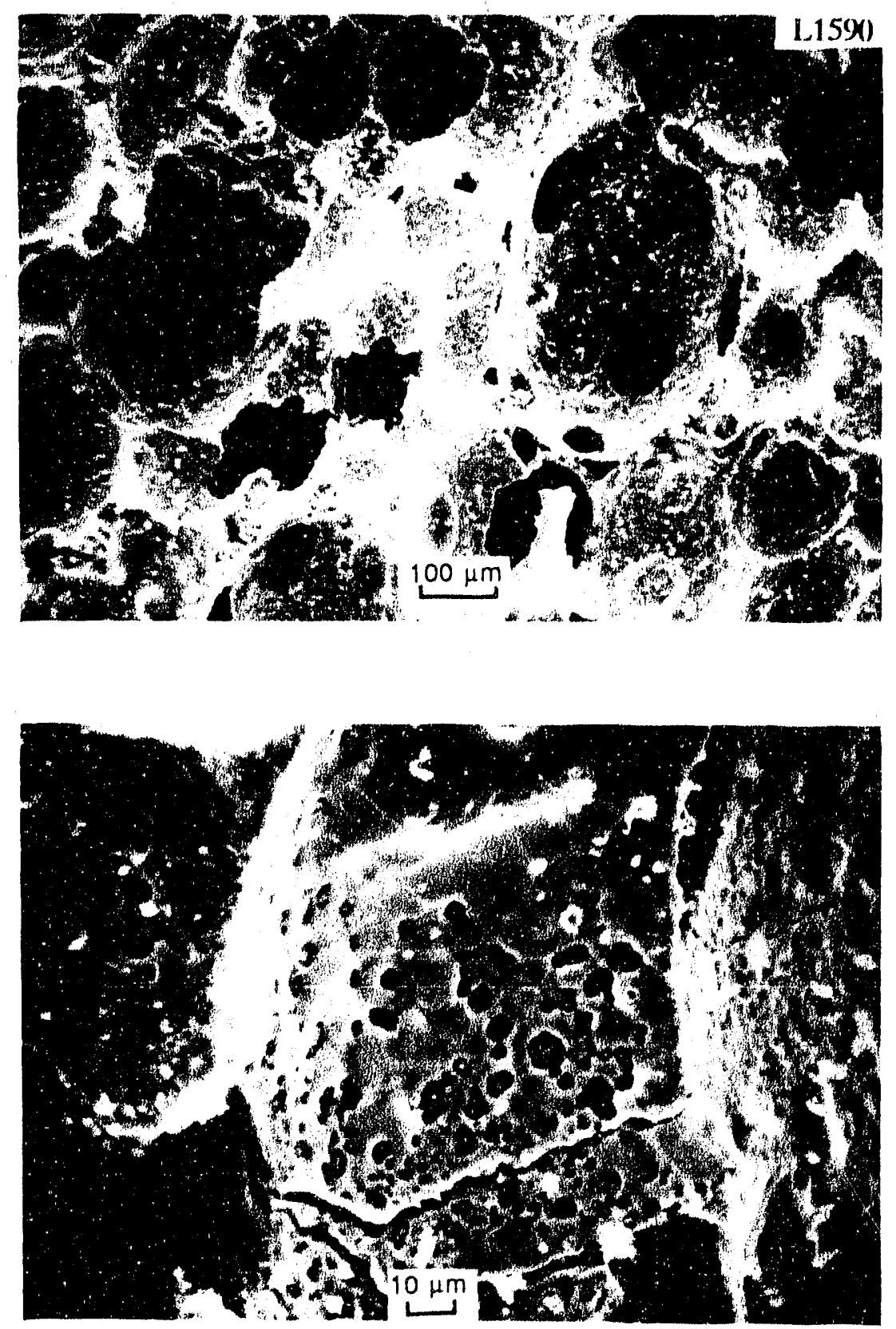

Fig. 18. Scanning electron micrographs of carbon foam exposed to $\mathrm{NiSi}-\mathrm{NiSi}_{2}$. One can see that the alloy has penetrated into the porous matrix by wetting the surface. Top: overview showing uniformity of the coating at $80 \times$ (bar $=$ $100 \mu \mathrm{m})$. Bottom: detail at 500x showing that the alloy forms a nearly continuouse film (bar $=10 \mu \mathrm{m}$ ). 


\section{CONCLUSIONS}

1. A new thermal storage system using germanium metal as the PCM and POCO AXF-5Q graphite as the container shows potentially improved performance over baseline salt systems. Important features of the metal PCM are high thermal conductivity and high volumetric heat of fusion. The graphite container is easily fabricated, inexpensive, lightweight, and tolerant of much higher temperatures than Haynes 188.

2. Adding silicon to the germanium improvcs wetting of the graphite. Titanium does not promote wetting over the long term because of TiC formation.

3. Both $\mathrm{NiSi}-\mathrm{NiSi}_{2}$ and $\mathrm{Mg}_{2} \mathrm{Si}-\mathrm{Si}$ eutectics cannot be contained directly in graphite because of chemical interactions at the interface and large differences in thermal expansion in the solid state.

4. An infiltration technique has been developed that shows promise for eliminating CTE-driven fracture, provided that the PCM is an alloy that wets carbon. Both CBCF and reticulated carbon foam appear to be suitable matrices. Long-term testing is needed to assess the stability of these composite PCMs.

5. Ternary $\mathrm{Mg}-\mathrm{Si}-\mathrm{Ge}$ and $\mathrm{Ni}-\mathrm{Si}-\mathrm{Ge}$ alloys have potentially attractive properties for PCMs. In particular, these systems contain narrow-melting compositions that can be chosen over a wide range of possible melting points.

\section{ACKNOWLEDGMENTS}

R. L. Beatty first suggested the concept of a graphite capsule with large internal cavities to contain the PCM. J. R. Mayotte prepared metallographic specimens and photomicrographs. W. P. Eatherly provided much helpful advice on graphite chemistry and properties.

We thank Miles Dustin of NASA Lewis Research Center for his support and encouragement of this work. The program was managed at ORNL by R. P. Wichner and M. Olszewski. 


\section{REFERENCES}

1. R. V. Boyle, M. G. Coombs, and C. T. Kudija, "Solar Dynamic Power Option for the Space Station," pp. 319-28 in Proceedings of the 23rd Intersociety Energy Conversion Engineering Conference, July 31-August 5, 1988, Denver, Colorado, ed. D. Y. Goswami, American Society of Mechanical Engineers, New York, 1988.

2. H. J. Strumpf, M. G. Coombs, and D. E. Lacy; "Advanced Space Solar Dynamic Receivers," pp. 357-65 in Proceedings of the 23rd Intersociety Energy Conversion Engineering Conference, July 31-August 5, 1988, Denver, Colorado, ed. D. Y. Goswami, American Society of Mechanical Engineers, New York, 1988.

3. E. J. Roschke, "Solar Dynamic Systems for Spacecraft Power Applications," AIAA Paper 80-0382, AIAA 24th Aerospace Sciences Meeting, Reno, Nev. (1986).

4. R. J. Lauf, T. B. Lindemer, and R. L. Pearson, "Out-of-Reactor Studies of Fission Product-Silicon Carbide Interactions in HTGR Fuel Particles," J. Nucl. Mater. 120(1), 6-30 (1984).

5. R. W. Olesinski and G. J. Abbaschian, "The Ge-C (Germanium-Carbon) System," Bull. Alloy Phase Diagrams 5(5), 484-36 (1984).

6. A. Adamson, Physical Chemistry of Surfaces, 4th Edition, pp. 332-68, Wiley, New York, 1982.

7. R. A. Crane and G. Bharadhwaj, "Thermal Performance of Specific Heat Receiver Concepts for Advanced Solar Dynamic Applications," pp. 943-51 in Proceedings of the 24th Intersociety Energy Conversion Engineering Conference, August 6-11, 1989,

Washington D.C., ed. W. D. Jackson, Institute of Electrical and Electronics Engineers, New York, 1989.

8. M. Hansen, Constitution of Binary Alloys, pp. 916-17, McGraw-Hill Book Co., New York, 1958.

9. P. Nash and A. Nash, Fr. 1755-56 in Binary Alloy Phase Diagrams, Vol. 2,

T. B. Massalski, ed., Amer. Soc. for Metals, Metals Park, Ohio, 1986.

10. A. A. Nayeb-Hashemi et al., pp. 1222-23 in Binary Alloy Phase Diagrams, Vol. 2, T. B. Massalski, ed., Amer. Soc. for Metals, Metals Park, Ohio, 1986. 
11. A. Nash and P. Nash, pp. 1230-32 in Binary Alloy Phase Diagrams, Vol. 2, T. B. Massalski, ed., Amer. Soc. for Metals, Metals Park, Ohio, 1986.

12. J. D. Cotton and L. M. Sedgwick, "Compatibility of Selected Superalloys with Molten LiF-CaF ${ }_{2}$ Salt," pp. 917-21 in Proceedings of the 24th Intersociety Energy Conversion Engineering Conference, August 6-11, 1989, Washington D.C., ed. W. D. Jackson, Institute of Electrical and Electronics Engineers, New York, 1989.

13. G. C. Wei and J M Robbins, Development and Characterization of Carbon-Bonded Carbon Fiber Insulation for Radioisotope Space Power Systems, ORNL/TM-9381, Martin Marietta Energy Systems, Inc., Oak Ridge Natl. Lab., June 1985. 
Appendix

Summary of Melting Tests

\begin{tabular}{|c|c|c|c|c|}
\hline Test & PCM alloy & Capsule geometry & Material & Thermal cycles $^{a}$ \\
\hline 1 & $\mathrm{Ge}$ & Sessile drop & Carbon planchette & $1 \mathrm{~h}^{b}$ \\
\hline 2 & $\mathrm{Ge}-0.5 \% \mathrm{Ti}$ & Sessile drop & Carbon planchette & $4 h_{h}^{b}$ \\
\hline 3 & $\mathrm{Ge}-0.5 \% \mathrm{Si}$ & Sessile drop & Carbon planchette & $4 h_{h}^{b}$ \\
\hline 4 & $\mathrm{NiSi}-\mathrm{NiSi}_{2}$ & Sessile drop & Carbon planchette & $4 h^{b}$ \\
\hline 5 & $\mathrm{Ge}$ & Test & 2020 Grade 1 & $637+$ \\
\hline 6 & $\mathrm{Ge}$ & Test & 2020 Grade 2 & 544 \\
\hline 7 & $\mathrm{Ge}-0.5 \% \mathrm{Ti}$ & Test & 2020 Grade 1 & $637+$ \\
\hline 8 & Ge-0.5\% Ti & Test & 2020 Grade 1 & $637+$ \\
\hline 9 & $\mathrm{Mg}_{2} \mathrm{Si}-\mathrm{Si}$ & Test & 2020 Grade 2 & 3 \\
\hline 10 & $\mathrm{Mg}_{2} \mathrm{Si}-\mathrm{Si}$ & Test & 2020 Grade 1 & 7 \\
\hline 11 & $\mathrm{NiSi}-\mathrm{NiSi}_{2}$ & Test & 2020 Grade 2 & 1 \\
\hline 12 & $\mathrm{Ge}-0.5 \% \mathrm{Si}$ & Test & 2020 Grade 2 & 52 \\
\hline 13 & $\mathrm{Ge}-0.5 \% \mathrm{Ti}$ & Test & 2020 Grade 2 & 52 \\
\hline 14 & $\mathrm{Ge}$ & Prototype, drilled & AXF-5Q & 3 \\
\hline 15 & $\mathrm{Ge}$ & Prototype, annulus & 2020 Grade 1 & $482+$ \\
\hline 16 & Empty & Test & 2020 Grade 1 & $591+$ \\
\hline 17 & $\mathrm{Ge}$ & Prototype, drilled & AXF-5Q & 3 \\
\hline 18 & $\mathrm{Ge}$ & Prototype, annulus & AXF-5Q & $495+$ \\
\hline 19 & $\mathrm{Mg}_{2} \mathrm{Si}-\mathrm{Si}$ & Test & $\begin{array}{l}2020 \text { Grade } 1 \\
\text { w/CBCF "wick" }\end{array}$ & $308+$ \\
\hline
\end{tabular}

${ }^{a}$ Each cycle includes $1 \mathrm{~h}$ at $773 \mathrm{~K}$ and $2 \mathrm{~h}$ at $1273 \mathrm{~K}$, as described in the test. " + " indicates that the capsule was intact after the indicated cycle and tests are continuing.

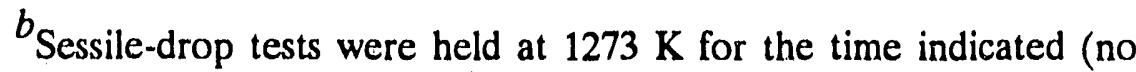
cycling). 

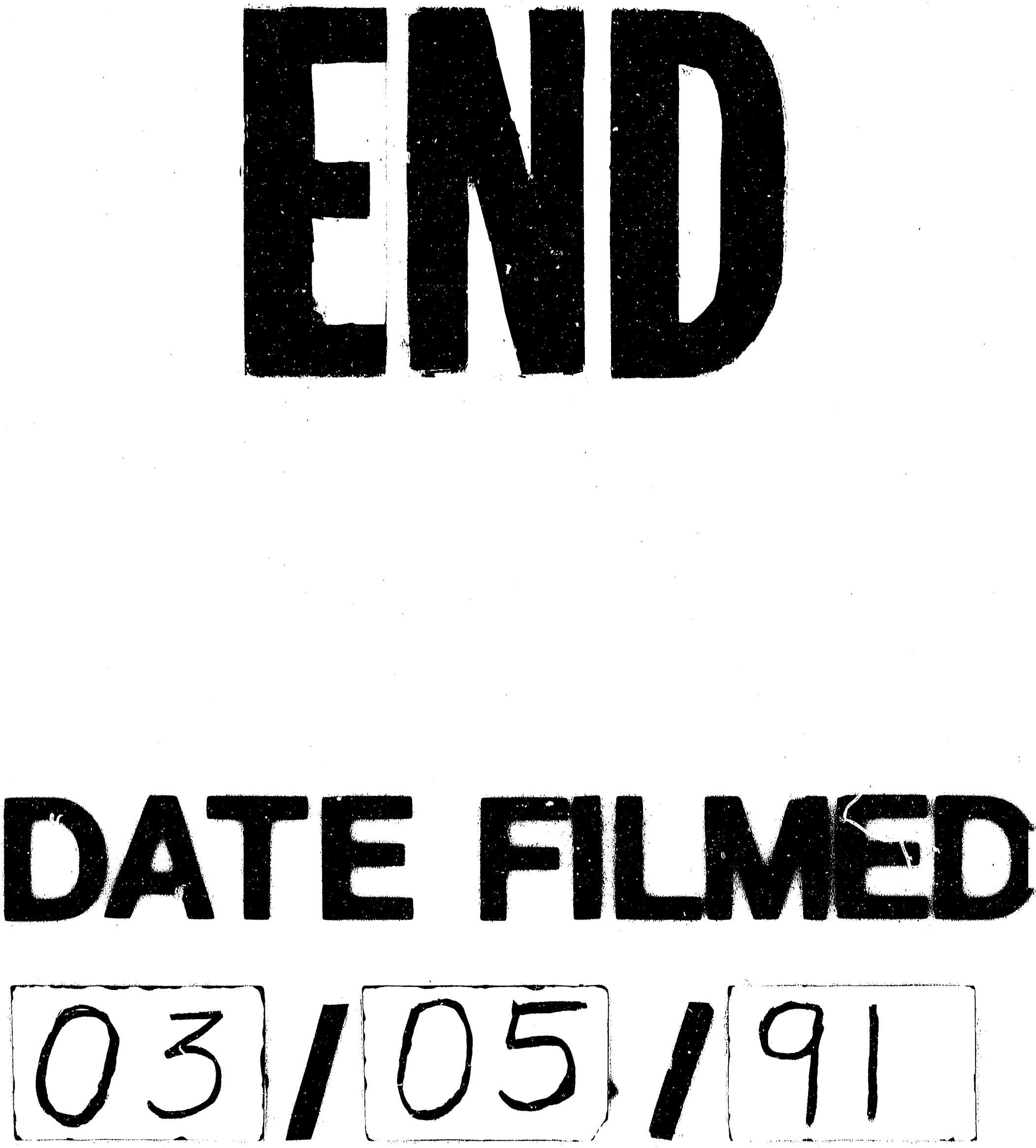